\title{
Polska bibliografia biblijna za lata 2016-2017
}

Polish Biblical Bibliography 2016-2017

\author{
KS. MARCIN BIEGAS - MIROS ŁAW BRUŻEK - KS. KAMIL GNIWEK \\ - MICHAŁ KLUKOWSKI - KS. STANIS ŁAW SADOWSKI - KS. NIKOS \\ M. SKURAS - KS. VALERY MARTSINOUSKI
}

Instytut Nauk Biblijnych, Katolicki Uniwersytet Lubelski Jana Pawła II

e-mail: biblical.annals@gmail.com

\section{Wykaz skrótów}

ABL - Analecta Biblica Lublinensia (Lublin, 2007-)

AK - Ateneum Kapłańskie (Włocławek, 1909-)

BibAn - The Biblical Annals (Lublin, 2011-)

BKK - Biblia. Krok po Kroku (Kraków, 2009-)

BPTh - Biblica et Patristica Thoruniensia (Toruń, 2008-)

CT - Collectanea Theologica (Lwów, 1931-1939, Warszawa, 1949/1950-)

CzST - Częstochowskie Studia Teologiczne (Częstochowa, 1973-)

EE - Extra Ecclesia (Lublin, 2014)

KStT - Kieleckie Studia Teologiczne (Kielce, 2002-)

NKB.NT - Nowy Komentarz Biblijny. Nowy Testament

NKB.ST - Nowy Komentarz Biblijny. Stary Testament

NSTB - Nowy Stownik Teologii Biblijnej (Kielce 2017)

PzST - Poznańskie Studia Teologiczne (Poznań, 1972-)

QChr - The Qumran Chronicle (Kraków, 1990-)

PJBR - The Polish Journal of Biblical Research (Kraków 2000-)

RBL - Ruch Biblijny i Liturgiczny (Kraków, 1948-)

RT ChAT - Rocznik Teologiczny Chrześcijańskiej Akademii Teologicznej (Warszawa, 1959-)

Sem - Seminare. Poszukiwania naukowe (Kraków, 1975-)

SiR - Społeczeństwo i Rodzina (Lublin, 2004-)

SJC - Scripta Judaica Cracoviensia (Kraków, 2002-)

SnR - Studia nad Rodzina (Warszawa, 1997-)

SO - Studia Oecumenica (Opole, 2001-)

SST - Sosnowieckie Studia Teologiczne (Kraków, 1993-)

StBob - Studia Bobolanum (Warszawa, 2001-)

StEl - Studia Elbląskie (Elbląg, 1999-)

StEt - Studia Ełckie (Ełk, 2000-)

StGd-Studia Gdańskie (Gdańsk, 1973-)

StKKot - Studia Koszalińsko-Kołobrzeskie (Koszalin, 1992-) 
StLeo - Studia Leopoliensia (Lwów, 2006-)

StPar - Studia Paradyskie (Gościkowo - Paradyż, 1985-)

StPel - Studia Pelplińskie (Pelplin, 1969-)

StSan - Studia Sandomierskie (1980 -)

StWar - Studia Warmińskie (Olsztyn, 1964-)

SW - Studia Wschodniostowiańskie (Białystok, 2001-)

ŚSHT - Śląkie Studia Historyczno-Teologiczne (Katowice, 1968-)

VA - Vita Academica (Kraków, 2001-)

Vox - Vox Patrum (Lublin, 1981-)

VV - Verbum Vitae (Kielce 2002-2009, Lublin, 2010-)

WPT - Wrocławski Przeglad Teologiczny (Wrocław, 1993-)

WStT - Warszawskie Studia Teologiczne (Warszawa, 1983-)

ZFK - Zeszyty Formacji Katechetów (Radom, 2001-)

ZNSBP - Zeszyty Naukowe Stowarzyszenia Biblistów Polskich (Warszawa, 2004-)

$\dot{Z} D$ - Życie Duchowe (Kraków)

ŻK-Życie Konsekrowane (Warszawa, 1993-)

\section{Część pierwsza: prace zbiorowe}

Chrostowski, W. - Kotecki, D. (red.), „Scrutamini Scripturas” (J 5,39). Ksiega jubileuszowa dla Księdza Biskupa Andrzeja W. Suskiego w 75. rocznice urodzin (Ad Multos Annos 19; Warszawa: Stowarzyszenie Biblistów Polskich 2016).

Green, J.B. - Brown, J.K. - Perrin, N. - Paprocki, R., Słownik nauczania Jezusa oraz tematów czterech Ewangelii. Komentarz Tematyczny do Nowego Testamentu (Warszawa: Vocatio 2017) I.

Jaromin, J. (red.), Oblicza miłosierdzia w Biblii (Bibliotheca Biblica; Wrocław: TUM 2016).

Krajewska, M. - Kulwicka-Kamińska, J. - Szulc, A. (red.), Święte księgi judaizmu, chrześcijaństwa i islamu w stowiańskim kręu kulturowym. Prace dedykowane Profesorowi Czesławowi Łapiczowi. II. Księgi wyznawców judaizmu i islamu. Historia - socjologia - sztuka (Toruń: Wydawnictwo UMK 2016).

Kubiś, A. - Napora, K. (red.), ,Niewiastę dzielna kto znajdzie?” (Prz 31,10). Rola kobiet w biblijnej historii zbawienia (ABL 14; Lublin: Wydawnictwo KUL 2016).

Kuśmirek, A. (red.), Symbolika ciała w Starym Testamencie (Warszawa: Wydawnictwo UKSW 2016).

Legutko, B. (red.), Wielka księga miłosierdzia: komentarze biblijne, nauczanie papieskie (Kraków: Wydawnictwo „M” 2016).

Niemas, T. (red.), Perspektywa egzystencjalna proegzystencji wierzacych w przekazie Pisma Świętego (Bibliotheca Biblica; Wrocław: TUM 2016).

Paciorek, A. - Mickiewicz, F. (red.), Biblia w liturgii Mszy Świętej. Adwent-Narodzenie Pańskie (W Drodze do Emaus 1; Częstochowa: Edycja Świętego Pawła 2016).

Paciorek, A. - Mickiewicz, F. (red.), Biblia w liturgii Mszy Świętej. Wielki Post (W Drodze do Emaus 2; Częstochowa: Edycja Świętego Pawła 2016).

Rambiert-Kwaśniewska, A. (red.), Synagoga w Ostii. Niemy świadek początków chrześcijaństwa (Archeolog Czyta Biblię; Wrocław: TUM 2016).

Witczyk, H. (red.), Nowy stownik teologii biblijnej (Lublin - Kielce: Towarzystwo Naukowe KUL - Wydawnictwo Jedność 2017). 
Wróbel, M. - Szymik, S. - Napora, K. (red.), Natchnienie Pisma Świętego w świetle świadectwa tekstów o nich samych (ABL 15; Lublin: Wydawnictwo KUL 2017).

Zawadzki, A. (red.), Radość ewangelii. Biblijne źródła chrześcijańskiej radości. (ABL 12; Lublin: Wydawnictwo KUL 2016).

Zielonka, I. (red.), Maryja Gwiazda Nowej Ewangelizacji. Teologia i duszpasterstwo (Teresin: Wydawnictwo Ojców Franciszkanów Niepokalanów 2017).

\section{Część druga: przekłady}

Bardski, K., „Przypowieści o Bożym miłosierdziu (Łk 15) - przekład alternatywny perspektywy interpretacji symbolicznej”, WStT 29/1 (2016) 118-132.

Krzyszczuk, Ł., „Św. Hieronim - Komentarz do Księgi Izajasza X 34, 1 - X 35, 10 [Commentarii in Esaiam, CPL 584], wstęp, przekład i komentarz", Vox 36/66 (2016) 527- 567.

Langkammer, H., Listy katolickie. List św. Jakuba, Pierwszy List św. Piotra, Drugi List św. Piotra, List św. Judy. Pismo Święte Starego i Nowego Testamentu w przekładzie z języków oryginalnych (Lublin: Wydawnictwo KUL 2016).

Nawrot, J., Pierwsza Księga Machabejska (NKB.ST 14.1; Częstochowa: Edycja Świętego Pawła 2016).

Popowski, R., Biblia pierwszego Kościoła (Prymasowska Seria Biblijna; Warszawa: Vocatio 2016).

Sikora, A.R., Knéga Kapłańskô. Leviticus. Z hebrajsczégò jãzëka na kaszëbsczi (Gdańsk: Zarząd Główny Zrzeszenia Kaszubsko-Pomorskiego 2017).

Sikora, A.R., Knéga wińdzieniô. Exodus. Z hebrajsczégò jãzëka na kaszëbsczi (Gdańsk: Zarząd Główny Zrzeszenia Kaszubsko-Pomorskiego 2016).

Tronina, A. - Walewski, P., Druga Księga Kronik (NKB.ST 10.2; Częstochowa: Edycja Świętego Pawła 2016).

Tronina, A., „«Psalmy Salomona» [Psalmi Salomonis], wstęp, przekład i przypisy”, Vox 36/66 (2016) 477-511.

Tronina, A., „Księga Ezdrasza”, Pismo Święte ST. Księgi historyczne. Przeklad ekumeniczny zj. hebrajskiego (Warszawa: Towarzystwo Biblijne w Polsce 2016) 353-366.

Tronina, A., „Księga Nehemiasza”, Pismo Święte ST. Księgi historyczne. Przekład ekumeniczny zj. hebrajskiego (Warszawa: Towarzystwo Biblijne w Polsce 2016) 369-388.

Wacławik, P., List do Efezjan. Nowy przekład dynamiczny opatrzony przypisami oraz komentarzem filologicznym, historycznym i teologicznym (Warszawa: Vocatio 2017).

Wacławik, P., List do Kolosan. Nowy przekład dynamiczny opatrzony przypisami oraz komentarzem filologicznym, historycznym i teologicznym (Warszawa: Vocatio 2016).

Wacławik, P., List do Rzymian. Nowy przekład dynamiczny opatrzony przypisami oraz komentarzem filologicznym, historycznym i teologicznym (Warszawa: Vocatio 2016).

Wojciechowski, M., Księga Barucha (NKB.ST 24.2; Częstochowa: Edycja Świętego Pawła 2016).

Wróbel, M., Targum Neofiti 1 - Księga Wyjścia. Tekst aramejski-przeklad, aparat krytycznyprzypisy (Biblia Aramejska 2; Lublin: Gaudium 2017). 


\section{Część trzecia: monografie}

Aboner, K., Bibliologica (Szczecin: My Book 2016).

Bartnicki, R., Biblia w liturgii dni powszednich. Komentarze do czytań mszalnych (Ząbki: Apostolicum 2016, wyd. II poprawione i uzupełnione).

Bocian, B.J., Jestem faryzeuszem, bracia...(Górna Grupa: Verbinum 2016).

Chrostowski, W., Uczynki miłosierdzia względem ciała i ducha w świetle Biblii (Kraków: Biały Kruk 2016).

Conder, Z., Cudowne uwolnienie z więzienia wedtug Dziejów Apostolskich w kontekście starotestamentalnej tradycji biblijnej (Warszawa: Towarzystwo Naukowe Franciszka Salezego 2016).

Czerski, J., Ewangelia i Listy św. Jana. Wprowadzenie literackie, historyczne i teologiczne (Opolska Biblioteka Teologiczna 156; Opole: Uniwersytet Opolski 2016).

Czerski, J., Методологія досліджень Нового Завіту (Львів: Філософсько-Богословський Факультет, Кафедра Біблійних Наук 2017).

Daigneault, A., Dobry Łotr. Tajemnica miłosierdzia (Kraków: Wydawnictwo Karmelitów Bosych 2017).

Iwański, D., Księga Lamentacji. II. Jahwe odbuduje? (rozdz. 3-5) (Księga Lamentacji; Toruń: Wydawnictwo UMK 2016).

Jasiński, A.S., Księga Proroka Ezechiela. Nowy komentarz. Wstęp (Opole: Redakcja Wydawnictw Wydziału Teologicznego Uniwersytetu Opolskiego 2016) I.

Karczewski, M., Baranek w Apokalipsie św. Jana. (Olsztyn: WT UWM 2016).

Kotecki, D., Con Gesu nella barca (Mc 4,35-41; 6,45-52; 8,13-21). Contributo allo studio del discepolato nel Vangelo di Marco (BPTh. Series Monographiae; Toruń: Wydawnictwo Naukowe UMK 2016).

Kreeft, P., I ty możesz zrozumieć Biblię (Kraków: Wydawnictwo „M” 2016).

Paciorek, A., Drugi List do Koryntian (NKB.NT 8; Częstochowa: Edycja Świętego Pawła 2017).

Parchem, M., Biblijny język aramejski: gramatyka, kompletne preparacje, słownik (Biblica et Judaica 5; Pelplin: Wydawnictwo „Bernardinum” 2016).

Pietkiewicz, R., Biblia Polonorum. Historia Biblii w języku polskim. I. Od początku do 1638 roku (Poznań: Pallottinum 2016).

Pilarczyk, K., Dialog katolicko-judaistyczny w perspektywie dokumentów Stolicy Apostolskiej (Instytut Religioznawstwa UJ, Polska Misja Katolicka w Anglii i Walii, Instytut Polski Akcji Katolickiej, Kraków: Wydawnictwo Antykwa 2016).

Piotrkowska-Dańkowska, M., Winnice Engaddi. Biblijna droga do spotkania z Oblubieńcem. Studium hermeneutyczne w oparciu o listy św. Teresy od Dzieciątka Jezus i Najświętszego Oblicza (Płock: Płocki Instytut Wydawniczy 2016).

Piwowar, A., Sktadnia języka greckiego Nowego Testamentu (Materiały Pomocnicze do Wykładów z Biblistyki 13; Lublin 2016).

Rosik, M., Ewangelia dla zabieganych, czyli rozważania dla tych, którzy sa po tej stronie nieba (Wrocław: TUM 2017).

Rosik, M., Kościót a Synagoga (30-313 po Chr.). Na rozdrożu (Wrocław: Chronicon 2016).

Rosik, M., W Nowym Testamencie wszystko po staremu? Konteksty Ewangelii (Kraków: Wydawnictwo „Serafin” 2016).

Rosik, M., W przestrzeni Stowa (Wrocław: TUM 2017).

Roszak, P., Wykład pierwszego listu do Tymoteusza. Super primam epistolam b. pauli ad Thimotheum lectura (Scholastica Thorunensia; Toruń: Wydawnictwo UMK 2016). 
Siwek, K., Honor sprawiedliwego $i$ wstyd bezbożnego w antropologicznokulturowej interpretacji Mdr 1-5 (Lingua Sacra. Monografie 6; Warszawa 2016).

Szczerbiński, W. - Podeszwa, P., Co katolik powinien wiedzieć o judaizmie (Poznań: WT UMK 2016).

Tronina, A., Drzewo życia w rajskim ogrodzie. Biblijne korzenie mistyki krzyża (Częstochowa: Edycja Świętego Pawła 2017).

Tronina, A., Księgi świętych tajemnic Henocha (Henoch Słowiański, 2 Hen) (Kraków: Enigma 2016).

Tronina, A., Poznaj swoja godność. Imiona chrzcielne w Polsce (Częstochowa: Edycja Świętego Pawła 2016).

Watson, J., Stowo hebrajskie na każdy dzień roku. Inspiracje ze Starego Testamentu (Warszawa: Vocatio 2017).

Watson, J.D. - Tasak, W., Słowo greckie na każdy dzień roku. Inspiracje z Nowego Testamentu (Warszawa: Vocatio 2017).

Zaklukiewicz, T., Nieśmiertelność sprawiedliwych. Idea nieśmiertelności sprawiedliwych w Księdze Mądrości (Wrocław: Tum 2017).

\section{Część czwarta: artykuły}

Adamczewski, B., „Intertekstualna funkcja cytatu z Księgi Ozeasza w Mateuszowej Ewangelii Dzieciństwa", CT 86/4 (2016) 125-138.

Aleksandrowicz, R. - Repucho, E., „Tekst natchniony w obliczu nowych technologii. Biblia Tysiąclecia w aplikacji na telefon. Perspektywa wydawcy”, TiC 36/4 (2016) 149-166.

Aleksandrowicz, R. - Repucho, E., „Tekst natchniony w obliczu nowych technologii. Biblia Tysiąclecia w aplikacji na telefon. Perspektywa odbiorcy", TiC 36/4 (2016) 167-184.

Aszyk, P., „Samarytanin na Areopagu”, StBob 1 (2016).

Baran, G.M., „Karanie narodu żydowskiego przez Boga jako wymiar Bożej $\pi \alpha \iota \delta \varepsilon i ́ \alpha$ według Drugiej Księgi Machabejskiej”, ŚSHT 49/2 (2016) 408-429.

Baran, G., „Obraz Boga w przekazie Czwartej Księgi Machabejskiej”, BibAn 6/3 (2016) 419-457.

Bardski, K., „Chrystologiczna interpretacja Księgi Ozeasza w starożytności i średniowieczu”, CT 86/4 193-204.

Bardski, K., „Czy Oblubienica rzeczywiście «znalazła pokój»? Dylematy translacyjne Pnp 8,10b”, VV 30 (2016) 43-51.

Baraniak, M., „Motif of «the city» in the Song of Songs”, Studia Biblica Slovaca VIII/1 (czerwiec 2016) 32-46.

Baraniak, M., „Ways of interpreting Tetragrammaton - word or sign”, Word in the cultures of the East: sound, language, book (red. P. Mróz - M. Ruchel - A. Wójcik) (Kraków: Wydawnictwo Libron - Filip Lohner 2016).

Baraniak, M., „The versions of Psalm 151 from the perspective of the Biblical and Semitic Rhetoric Analysis", Studi del quinto convegno RBS (red. R. Meynet - J. Oniszczuk) (Rhetorica Biblica et Semitica 9; Leuven: Peeters 2017) 231-250.

Bartnicki, R., „Czym jest podejście, a czym metoda?”, CT 86/2(2016) 203-206.

Bartnicki, R., „Proces rzymski Jezusa w opisie Ewangelii według św. Marka (Mk 15,1-15)”, ,,Scrutamini Scripturas" (J 5,39). Księga jubileuszowa dla Księdza Biskupa Andrzeja W. Suskiego w 75. rocznice urodzin (red. W. Chrostowski - D. Kotecki) (Ad Multos Annos 19; Warszawa: Stowarzyszenie Biblistów Polskich 2016) 48-69. 
Bartoszewicz, K.D., „Komplementarność tekstu oryginalnego i tłumaczeń Biblii jako konsekwencja teologicznego interpretowania tekstu", WStT 29/3 (2016) 174-184.

Bąk, T., „«Jezus rzekł do nich: Moja żona». Znaczenie kontrowersyjnego manuskryptu koptyjskiego w świetle współczesnej wiedzy i polemiki”, CT 86/1 (2016) 61-84.

Bąk, T., „Harvard Lycopolitan John - kolejne fałszerstwo? Koptyjski manuskrypt w świetle Ewangelii Żony Jezusa i współczesnych badań”, BibAn 6/2 (2016) 227-249.

Bednarski, M., „Motywy Pięcioksięgu w Księdze Ozeasza”, CT 86/4 (2016) 33-62.

Bieliński, K., „Jezusowa «wizja pokoju» w ujęciu synoptyków”, VV 30 (2016) 97-120.

Bladyniec-Sośnier, A., „Pojęcia wyrażające cnotę miłości w Biblii”, CT 87/1 (2017) 75-90.

Blaza, M., „Symbolika światła”, ŻD 86 (2016) 43-50.

Błąd, M., „Między ekonomią a teologią: ekonomiczne archetypy ziemi w Pięcioksięgu”, CT 86/3 (2016) 27-54.

Borkowska, T., „Współczesne nurty w interpretacji Słowa Bożego”, StPar 26 (2016) 7-17.

Chrostowski, W., „Asyryjska diaspora Izraelitów jako wyzwanie dla biblistyki i asyriologii”, $C T$ $86 / 3$ (2016) 5-26.

Chrostowski, W., „Biblia Hebrajska, Biblia Aramejska, Biblia Grecka. Egzegeza i teologia biblijna jako kontekst nauczania Jubilata”, Opere et Veritate. Arcybiskup Stanisław Gadecki. 25-lecie Sakry Biskupiej. 15-lecie Posługi w Archidiecezji Poznańskiej (red. J. Stranz - G. Piskorz) (Poznań: Wydawnictwo Święty Wojciech 2017) 149-155.

Chrostowski, W., „Chronologia działalności proroka Ozeasza”, CT 86/4 (2016) 7-32.

Chrostowski, W., „Europa a chrześcijaństwo - perspektywa biblijna. Inspiracje Josepha Ratzingera/Benedykta XVI", Chrześcijańska koncepcja Europy i Polski w perspektywie nauczania Kardynała Josepha Ratzingera/Benedykta XVI (red. H. Czakowska - M. Kucinski) (Bydgoszcz: Centrum Studiów Ratzingera - Wydawnictwo Kujawsko-Pomorskiej Szkoły Wyższej w Bydgoszczy 2017) 63-80.

Chrostowski, W., „Gdy Bóg przemówił po grecku. Septuaginta jako świadectwo gruntownej transpozycji językowej”, Poradnik Językowy 5 (2016) 60-70.

Chrostowski, W., „Kiedy Bóg płacze... Trwałość przymierza Boga z Izraelem w świetle Oz 1,2-2,3”, ,, Scrutamini Scripturas” (J 5,39). Księga jubileuszowa dla Księdza Biskupa Andrzeja W. Suskiego w 75. rocznicę urodzin (red. W. Chrostowski - D. Kotecki) (Ad Multos Annos 19; Warszawa: Stowarzyszenie Biblistów Polskich 2016) 70-98.

Chrostowski, W., „Ku katolickiej teologii judaizmu. Inspiracje kard. J. Ratzingera/Benedykta XVI”, Studia Nauk Teologicznych PAN 11 (2016) 185-205.

Chrostowski, W., „Kwestie terminologiczne w egzegezie biblijnej [odpowiedź ks. prof. Romanowi Bartnickiemu]", CT 86/2 (2016) 207-208.

Chrostowski, W., „La Bibbia nella cultura e nella coscienza europea”, La Bibbia nella cultura e nell'arte (Grandi Opere; UTET - Fondazione Vaticana Joseph Ratzinger-Benedetto XVI 2016) 1-21.

Chrostowski W., „«Mężczyzną i kobietą stworzył ich» (Rdz 1,27). Ludzka cielesność i płciowość jako dar i zobowiązanie”, $A K$ 168/1 (2017) 9-18.

Chrostowski, W., "Qumran in the theology of Benedict XVI”, Cooperatores Veritatis. Scritti in onore del Papa emerito Benedetto XVI per il 90 compleanno. Tributes to Pope emeritus Benedict XVI on his $90^{\text {th }}$ birthday (red. P. Azzaro - F. Lombardi) (Cittâ del Vaticano: Libreria Editrice Vaticana 2017) 89-115.

Chrostowski, W., „Ratowanie i ochrona życia ludzkiego w tradycji judaistycznej”, Pomoc świadczona ludności żydowskiej przez Polaków w latach 1939-1945 ze szczególnym uwzględnieniem Kielecczyzny (red. J. Gapys - A. Dziarmaga) (Kielce - Wrocław: Kappadruk Drukarnia 2016) 25-35. 
Chrostowski, W., „Syryjska diaspora Izraelitów jako wyzwanie dla biblistyki i asyriologii”, $C T$ 86/3 (2016) 5-26.

Chrostowski, W., „Wokół historyczności Księgi Jonasza: «kompozycja wyobrażona»?”, ZNSBP 13 (2016) 311-328.

Chrostowski, W., „Współczesne przekłady biblijne na język białoruski”, Święte księgi judaizmu, chrześcijaństwa i islamu w stowiańskim kręgu kulturowym. Prace dedykowane Profesorowi Czesławowi Łapiczowi, III. Słowiańscy chrześcijanie Wschodu i Zachodu. Język - dialektpiśmiennictwo (red. M. Krajewska - J. Kulwicka-Kamińska - A. Szulc) (Toruń: Wydawnictwo Naukowe UMK 2016) 147-166.

Czerski, J., „Droga ucznia Jezusa”, Via Crucis. Droga Krzyżowa. Historia i duchowość nabożeństwa oraz antologia współczesnych rozważań (red. R.S. Pujsza) (Warszawa: Zgromadzenie Męki Jezusa Chrystusa / Fundacja Żywe Słowo 2017) 218-231.

Czyżewski, B., „Błogosławieni, którzy wprowadzają pokój (Mt 5,9) w interpretacji Ojców Kościoła", VV 30 (2016) 231-257.

Czyżewski, B., „Patrystyczna interpretacja Rdz 2, 7: „Pan Bóg ulepił człowieka z prochu ziemi i tchnął w jego nozdrza tchnienie życia”, Vox 36/65 (2016) 141-154.

Ćwikła, J., „Krytyczne spojrzenie proroków na bogaczy i bogactwo”, Studia Gnesnensia 30 (2016) 301-326.

Ćwikła, J., „Umiejętność rozeznawania wartości doczesnych w perspektywie królestwa Bożego (Łk 14,15-24)", BPTh 10/1 (2017) 11-33.

Czarnuch, M., „The Good News about Death: Predications of Jesus' Death in the First Commentaries on the Gospel of Mark", Scripta Classica 12 (2015) 151-166.

Dąbek, T.M., „Matki nadające imiona dzieciom w biblijnym Izraelu”, Rodzina i edukacja w zmaganiu o przyszłość Europy (red. E. Osewska) (Tarnów: Wydawnictwa Państwowej Wyższej Szkoły Zawodowej w Tarnowie 2016) 151-159.

Dąbek, T.M., „Miłosierny, ale wymagający Chrystus w Ewangelii św. Jana”, Oblicza miłosierdzia w Biblii (red. J. Jaromin) (Bibliotheca Biblica; Wrocław: TUM 2016) 229-246.

Dąbek, T.M., „Miłość rodzinna źródłem radości według Pisma Świętego”, SST 13 (2017) 12-24.

Dąbek, T.M., „«Nie zasmucajcie Ducha Świętego» (Ef 4,30). Pełna miłości troska Ducha Świętego o zbawienie ludzi”, Duch Święty (Scripturae Lumen. Biblia i Jej Oddziaływanie 8) (red. G.M. Baran - J. Królikowski - P. Łabuda) (Tarnów: Biblos 2016) 155-168.

Dąbek, T.M., „Wspomnienie o ś.p. Ojcu Augustynie Jankowskim, profesorze i redaktorze Biblii Tysiąclecia”, Biblia Tysiąclecia jako wyzwanie. Język - kultura - duchowość (red. M. Pawlik) (Kraków: Wydawnictwo Benedyktynów Tyniec 2016) 23-37.

Dąbek, T.M., „Znaczenie mniszych ślubów stałości i przemiany obyczajów oraz ich biblijne uzasadnienie", RBL 69 (2016) 5-22.

Dąbrowa, E., „The «Camp of the Assyrians» and the Third Wall of Jerusalem”, SJC 13 (2015) 19-30.

Dąbrowski, M., „Rozmowa Jezusa z Nikodemem (J 3,1-21) jako dyskusja rabiniczna”, WPT 24/1 (2016) 55-66.

Dublański, R. - Pilarczyk, K., „Moses Mendelssohn a judaizm i kultura żydowska”, Studia Gdańskie 38 (2016) 75-87.

Dziadosz, D., „Deuteronomistyczna lektura prześladowania madianickiego. Studium historyczno-krytyczne Sdz 6,1-10", TiC 35/3 (2016) 77-105.

Dziadosz, D., „Obcy w religijnym i społeczno-kulturowym kontekście Biblii Hebrajskiej”, Ethos 30/1 (2017) 19-39. 
Dziadosz, D., „Źródła o Toli i Jairze w deuteronomistycznej strukturze Księgi Sędziów”, CT 86/3 (2016) 55-90.

Dziewiecki, M., „Miłosierny ojciec i marnotrawny syn: analiza biblijna i psychopedagogiczna”, ZFK 62 (2016) 89-107.

Dzik, M., „Nie upijajcie się winem..., ale napełniajcie się Duchem” (Ef 5,18). Relacja «Duch alkohol» w Biblii", BPTh 10/1 (2017) 35-63.

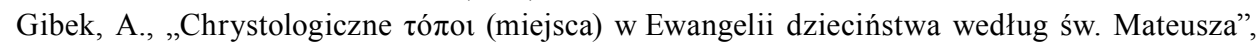
RBL 69/3 (2016) 217-236.

Grochowski, Z., „Apokalipsa św. Jana - księgą grozy czy radości?”, Radość Ewangelii. Biblijne źródła chrześcijańskiej radości (red A. Zawadzki) (ABL 13; Lublin: Wydawnictwo KUL 2016) 193-221.

Grochowski, Z., „L'incoronazione di spine (Mc 16,15-20a). Tortura fisica, subita da Gesù, o piuttosto la derisione della Sua dignità regale", BibAn 6/4 (2016) 655-688.

Grochowski, Z., „«Kogo szukacie?». Pytanie retoryczne kategorii quaesitum w J 18,4.7”, „Scrutamini Scripturas” (J 5,39). Księga jubileuszowa dla Księdza Biskupa Andrzeja W. Suskiego w 75. rocznice urodzin (red. W. Chrostowski - D. Kotecki) (Ad Multos Annos 19; Warszawa: Stowarzyszenie Biblistów Polskich 2016) 99-112.

Grochowski, Z., „«Światłość w ciemności świeci i ciemność jej nie zaskoczyła / nie przyłapała». Narracyjne uzasadnienie nowego thumaczenia J 1,5", StEl 17 (2016) 119-133.

Grochowski, Z., „Nawrócenie św. Piotra w czwartej Ewangelii (J 21,1-19). «Rehabilitacja» ucznia po trzykrotnym zaparciu się Mistrza", Studia z biblistyki (red. R. Bartnicki) (Warszawa: Wydawnictwo UKSW 2016) IX, 51-72.

Hałas S., „Szukać pokoju i dążyć do niego (1 P 3,11). Pojęcie pokoju w Listach św. Piotra”, VV 30 (2016) 179-194.

Haręzga S., „Spotkania ze Zmartwychwstałym”, ŻD 86 (2016) 33-42.

Janczak, G., „Symbolika światła w narracji synoptyków o przemienieniu Jezusa”, VV 29 (2016) 199-225.

Janik, M., „Azazel a zakazany kult w kontekście dnia przebłagania. Wzajemne przenikanie kultów i ich wpływ na motyw Azazela w Starym Testamencie", Veritati et Caritati 6 (2016) 243-257.

Janik, M., „Lilit - między mitem a Biblią”, StEł 18/1 (2016) 67-76.

Jaromin, J., „Droga wiary i wzrostu duchowego w opowiadaniu o uczniach idących do Emaus (Łk 24, 13-35)", WPT 23/1 (2015) 69-83.

Jaromin, J., „Miłosierdzie Boże w tajemnicy krzyża i zmartwychwstania. Zarys biblijno-teologiczny”, Oblicza miłosierdzia w Biblii (red. J. Jaromin) (Bibliotheca Biblica; Wrocław: TUM 2016) 247-260.

Jasiński, A.M., „Prorokini Debora - «wskrzesicielka» nadziei Izraela. Studium egzegetyczno-teologiczne Dz 4-5", BibAn 7/4 (2017) 415-439.

Jelonek, T., „Istotne znaczenie historycznego kontekstu Bożego Objawienia”, StLeo 9 (2016) 45-50.

Jezierska, E.J., „Pawłowe metafory chrztu”, $Z$ ZK 1/123 (2017).

Jezierska, E.J., „Pismo Święte o dziecięctwie Jezusa”, ŻK 2/118 (2016).

Jonczyk, W., „Relacyjne aspekty teologii Ewangelii i Listów św. Jana”, StBob 1 (2017) 177-193.

Jóźwiak, M., „«Princeps exegetarum» a język hebrajski na podstawie «Quaestiones Hebraicae in Genesim»”, Vox 36/65 (2016) 185-199.

Jóźwiak, M., „Gomer - antyideał żony czy wzorcowa metafora relacji oblubieńczej na podstawie Hieronimowego komentarza do Oz 1-3?", Vox 36/66 (2016) 169-178.

Jóźwiak, M., „Typologia żony Hioba w «Komentarzu do historii Hioba» Filipa Prezbitera na tle wybranych patrystycznych dzieł egzegetycznych”, „Niewiaste dzielnq kto znajdzie?” 
(Prz 31,10). Rola kobiet w biblijnej historii zbawienia (red. A. Kubiś - K. Napora) (ABL 14; Lublin: Wydawnictwo KUL 2016) 159-169.

Kamieński, Ł., „Aktualizacja Pisma Świętego według dokumentu Papieskiej Komisji Biblijnej «Interpretacja Biblii w Kościele» jako nowy sposób odniesienia słowa Bożego do życia”, $R B L$ 69/3 (2016) 197-215.

Kardyś, W., „Określenia, imiona i personifikacje demonów oraz ich pochodzenie według apokryficznego Testamentu Salomona", StPel 49 (2016) 133-145.

Kardyś, W., „Charakterystyka i pochodzenie demonów rodzaju żeńskiego w Testamencie Salomona”, StKKot 23 (2016) 31-42.

Kardyś, W., „Nowotestamentalne terminy greckie wyrażające miłosierdzie na tle słownictwa hebrajskiego oraz greki starotestamentalnej i klasycznej”, „Scrutamini Scripturas” (J 5,39). Księga jubileuszowa dla Księdza Biskupa Andrzeja W. Suskiego w 75. rocznicę urodzin (red. W. Chrostowski - D. Kotecki) (Ad Multos Annos 19; Warszawa: Stowarzyszenie Biblistów Polskich 2016) 149-163.

Kasiłowski, P., „Małżeństwo chrześcijańskie (Ef 5,21-33)”, StBob 3 (2016).

Kasiłowski, P. „Miłosierdzie w Nowym Testamencie”, StBob 1 (2016).

Kasiłowski, P. „Pobyt Jezusa w Samarii (J 4,1-42)”, StBob 2 (2016).

Klukowski, M., „Funkcja żony Piłata w Ewangelii według Mateusza $(27,19)$,, „Niewiastę dzielna kto znajdzie?” (Prz 31,10). Rola kobiet w biblijnej historii zbawienia (red. A. Kubiś - K. Napora) (ABL 14; Lublin: Wydawnictwo KUL 2016) 257-276.

Klukowski, M., „Luterańska hermeneutyka biblijna i jej współczesne wyzwania w świetle dokumentu «Na początku było Słowo». Biblia w życiu wspólnoty luterańskiej”, SO 16 (2016) 233-252.

Kl’usková, M., „Prawda o Bogu i Jego planie dla Izraela w Ps 105 i 106”, BibAn 7/2 (2017) 207-233.

Knut, T., „Psalm 1 jako zachęta do czytania i studiowania Pisma Świętego”, CT 86/2 (2016) 51-68.

Kołosowski, T., „«[Mulier] salvabitur per filiorum generationem» (1 Tm 2,15) w interpretacji wybranych dzieł łacińskich Ojców Kościoła”, Sem 37/4 (2016) 151-162.

Korzec, C., „«Gdzie Abel, brat twój?» (Rdz 4, 9). Strategia miłosierdzia”, Oblicza miłosierdzia $w$ Biblii (red. J. Jaromin) (Bibliotheca Biblica; Wrocław: TUM 2016) 41-60.

Kosendiak, M., „Biblia na Tysiąclecie Chrztu Polski”, Pamięć i Przyszłość 3 (2016).

Kot, T., „Rady Ewangeliczne”, ŻD 85 (2016) 11-18.

Kotecki, D., „Chrzest «w imię Ojca i Syna, i Ducha Świętego» (Mt 28,19) w ujęciu biblijnym: od egzegezy do aktualizacji”, TiC 35/3 (2016) 11-37.

Kowalski, J.K., „Aramejskie rękopisy Księgi Tobiasza z Qumaran (4Q 196-200) - historia i egzegeza", BibAn 7/3 (2017) 323-345.

Kowalski, M., „Nowe wino w starych bukłakach? Analiza socjoretoryczna Ef 5,21-33”, „Niewiaste dzielna kto znajdzie?” (Prz 31,10). Rola kobiet w biblijnej historii zbawienia (red. A. Kubiś K. Napora) (ABL 14; Lublin: Wydawnictwo KUL 2016) 393-418.

Kowalski, M., „Powołani do życia w pokoju (1 Kor 7,15). Lektura socjoretoryczna «przywileju Pawłowego» w 1 Kor 7,12-16", VV 30 (2016) 121-152.

Kowalski, M., „Retoryka i socjoretoryka w lekturze tekstów Nowego Testamentu. Cz. 1: Retoryka i nowe podejście do tradycji ustnej", BibAn 6/4 (2016) 611-654.

Kowalski, M., „Retoryka i socjoretoryka w lekturze tekstów Nowego Testamentu. Cz. 2: Socjoretoryka - projekt holistycznej lektury tekstu", BibAn 7/1 (2017) 107-147.

Kowalski, M., „Nowe życie jako ziarno gorczycy. Spójność argumentacji retorycznej Pawła w Rz 5-8", BibAn 7/4 (2017) 459-485.

Kozłowski, M.J., „Jezus jako filozoficzna arché w Liście do Kolosan 1,18”, WStT 29/4 (2016) 178-187. 
Krawczyk, M., „Czystość a idea wybrania człowieka we fragmentach Księgi Mądrości. Analiza i egzegeza trzech użyć słów z rdzeniem $\kappa \alpha \theta \alpha \rho(\operatorname{Mdr} 2,16 ; 14,24 ; 15,7)$ w ich najbliższym kontekście literackim", TiC 32/4 (2015) 67-89.

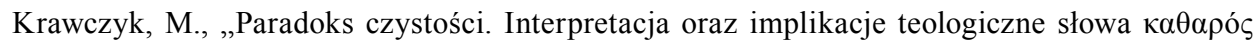

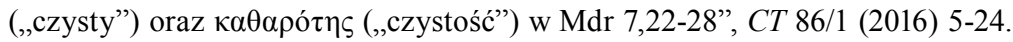

Krawczyk, R., „Gender w świetle biblijnej nauki o kobiecie i małżeństwie”, StEl 16 (2015) 207-219.

Kręcidło, J., „Koncepcja honoru rodziny w Ewangelii według św. Marka”, AK 166/1 (2016) 12-26.

Kubiś, A., „«Miłości pragnę, nie krwawej ofiary». Relektura Oz 6,6 w Ewangelii według św. Mateusza", CT 86/4 (2016) 103-124.

Kubiś, A., „Radość Przyjaciela Oblubieńca z powodu głosu Oblubieńca w J 3,29”, Radość Ewangelii. Biblijne źródła chrześcijańskiej radości (red. A. Zawadzki) (ABL 13; Lublin: Wydawnictwo KUL 2016) 163-192.

Kubiś, A., „Uboga wdowa - symbol Izraela, wzór ucznia, ikona Chrystusa”, ,Niewiastę dzielna kto znajdzie?” (Prz 31,10). Rola kobiet w biblijnej historii zbawienia (red. A. Kubiś - K. Napora) (ABL 14; Lublin: Wydawnictwo KUL 2016) 287-312.

Kubiś, A., „Znaczenie pozycji aniołów w grobie Jezusa w J 20,12”, BibAn 6/3 (2016) 459-493.

Kubiś, A., „Rhetorical Syncrisis in the Johannine Presentation of Jesus and Peter”, BibAn 7/4 (2017) 487-529.

Kubski, G., „Tyniecki przekład Ewangelii wobec koniunktur kultury religijnej”, ZNBP 13 (2016) 329-356.

Kucharski, J., „Autentyczna Maria z Magdali w interpretacji kanonicznych Ewangelii”, „Niewiaste dzielna kto znajdzie?" (Prz 31,10). Rola kobiet w biblijnej historii zbawienia (red. A. Kubiś K. Napora) (ABL 14; Lublin: Wydawnictwo KUL 2016) 365-392.

Kucharski, J., „Biblijne źródła uczynków miłosierdzia względem ciała”, ZFK 62 (2016) 56-69.

Kucharski, J., „Boży szlak dynastii Dawidowej w chaosie ludzkich losów. Egzegeza, wymowa teologiczna i walor aktualności Psalmu 2”, „Przyjdź Królestwo Twoje”. Księga pamiątkowa dedykowana Jego Ekscelencji Księdzu Biskupowi Henrykowi Tomasikowi w siedemdziesiata rocznice urodzin (red. M. Jagodziński - J. Wojtkun) (Radom: Radomska Biblioteka Teologiczna 2016) 229-244.

Kucharski, J., „Chwalcie Go dźwiękiem rogu, chwalcie na harfie i cytrze! (Ps 150,3). Instrumenty muzyczne w psalmach na przykładzie Ps 150. Przyczynek do instrumentologii biblijnej Psałterza”, Musicam sacram dilexit. Księga pamiątkowa dedykowana Księdzu Henrykowi Ćwiekowi profesorowi wyższych seminariów duchownych w Sandomierzu i Radomiu (red. M. Jagodziński - S. Kowalik - A. Wąsik) (Radom: Wydawnictwo Diecezji Radomskiej AVE 2017) 221-244.

Kucharski, J., „Pielgrzymowanie w Biblii. Od Abrahama do Chrystusowego Kościoła. (Zarys)”, Piesza Pielgrzymka Radomska. Historia i teraźniejszoś (red. L. Domagała - J. Kucharski) (Radom: KSM Radom 2016) 11-18.

Kusz, T., „Natura miłosierdzia według relacji o spotkaniu Jezusa i celnika Zacheusza (Łk 19,110)", Oblicza miłosierdzia w Biblii (red. J. Jaromin) (Bibliotheca Biblica; Wrocław: TUM 2016) 171-197.

Kuśmirek, A., „Aramejska wersja Księgi Ozeasza”, CT 86/4 (2016) 173-192.

Kuśmirek, A., „Gwiazda Jakuba” (Lb 24,17) i jej interpretacje”, VV 29 (2016) 41-65.

Kwiatkowski, D., „Eklezjalny wymiar głoszenia Słowa Bożego w świetle adhortacji apostolskiej Benedykta XVI Verbum Domini”, TiC 33/1 (2016) 11-28.

Lasek, P., „Il carattere letterario dell'episodio di Melchisedek (Gn 14,18-20)”, StSan 23 (2016) 183-196. 
Laskowski, Ł., „Relacja arcykapłan - kapłani według Drugiej Księgi Machabejskiej”, Veritati et Caritati 6 (2016) 13-38.

Laskowski, Ł., „Symbolika światła w literaturze dydaktycznej Starego Testamentu”, VV 29 (2016) 67-98.

Lemański, J., „«Nie zawiążesz pyska wołu podczas młócki» (Pwt 25,4). Prawo starożytnego Izraela w obronie właściwego stosunku człowieka do zwierząt?, StPar 26 (2016) 55-69.

Lemański, J., „W poszukiwaniu najstarszej literackiej wersji «cudu nad morzem» (Wj 13,17-15,21)”, BibAn 6/1 (2016) 5-44.

Linke, W., „Bóg bogaty w miłosierdzie (Ef 2, 4)”, Oblicza miłosierdzia w Biblii (red. J. Jaromin) (Bibliotheca Biblica; Wrocław: TUM 2016) 275-316.

Linke, W., „Czy kobieta jest chwałą mężczyzny (1 Kor 11,7)? Pojęcie doxa między teologią, ideologią a słownikiem, ,Scrutamini Scripturas” (J 5,39). Księga jubileuszowa dla Księdza Biskupa Andrzeja W. Suskiego w 75. rocznicę urodzin (red. W. Chrostowski - D. Kotecki) (Ad Multos Annos 19; Warszawa: Stowarzyszenie Biblistów Polskich 2016) 197-216.

Lipiński, E., „Pierwotne brzmienie tekstu? Refleksje nad krytyką tekstualną Biblii”, BibAn 6/2 (2016) 169-181.

Łabuda P., „Mysterium Incarnationis - Mysterium Misericordiae w najstarszych warstwach Prologu Ewangelii św. Jana", Oblicza miłosierdzia w Biblii (red. J. Jaromin) (Bibliotheca Biblica; Wrocław: TUM 2016) 199-228.

Łaszkiewicz, Ł., „Wiara jako warunek biblijnego uzdrowienia. Uzdrowienie jako znak budzący wiarę", StPar 26 (2016) 73-87.

Malina, A., „Prawda w ewangeliach. Znaczenie szczegółów narracji dla badań historycznych i literackich", BibAn 7/3 (2017) 347-358.

Maniecka, E., „Dolina Gehenny obrazem potępienia?”, RBL 69/3 (2016) 237-251.

Matuszewski, D., „Obraz Kościoła jako Oblubienicy Chrystusa w Pawłowym Liście do Efezjan”, $\dot{Z} K$ 2/124 (2017).

Matuszewski, D., „Świątynia, Pawłowy obraz Kościoła”, ŻK 5/127 (2017).

Mazurek, P., „Miłosierdzie w przypowieściach Jezusa w Ewangelii wg św. Łukasza”, Teologiczne Studia Siedleckie 13 (2016) 7-23.

Miduch, E.M., „«Zasiądzie w pokoju na wieki»” (2 Bar 73,1). Pokój jako element mesjańskiej rzeczywistości eschatologicznej w Syryjskiej Apokalipsie Barucha”, VV 30 (2016) 79-93.

Miduch, M., „Biblijny model życia poświęconego Bogu”, ŻD 85 (2016) 5-10.

Miduch, M., „Miłosierdzie przewyższające śmierć”, ŻD 88 (2016) 69-76.

Miduch, M., „Pismo zainspirowane zmartwychwstaniem”, ŻD 86 (2016) 25-32.

Miduch, M., „Z chasydem za rękę ... w szabat”, ŻD 87 (2016 ) 5-12.

Mielcarek, K., „Ewangelie dzieciństwa. Między Scyllą faktografii i Charybdą mitu”, ZNSBP 13 (2016) 357-368.

Mielcarek, K., „Motyw gwiazdy w Ewangelii według św. Mateusza (2,1-12)”, VV 29 (2016) 175-197.

Mielcarek, K., „Zachariasz - kapłan, ojciec, ofiarnik”, BibAn 7/3 (2017) 359-373.

Muszytowska, K.D., „«Owoc sprawiedliwości jest zasiewany w pokoju przez czyniących pokój» (Jk 3, 18). Socjoretoryczna analiza koncepcji pokoju w Liście Jakuba”, VV 30 (2016) 153-178.

Najda, A.J., „Małżonkowie w służbie ewangelizacji w pierwotnym Kościele”, SnR 19/2 (2015) 27-48.

Nalewaj, A., „Kościół Janowy jako «antyspołeczność» w socjolingwistycznej perspektywie Bruce'a J. Maliny", StWar 53 (2016) 161-177.

Napora, K. - Lakhmitskaya, T., „I widział Bóg, że światło było dobre...” (Rdz 1,4). Motyw światła w kapłańskim opowiadaniu o stworzeniu (Rdz 1,1-2,4a)", VV 29 (2016) 17-40. 
Nawrot, J., „Teologiczny obraz twierdzy jerozolimskiej w 1 Mch 1,33-38 i jej oblężenie przez wojska Judy w 4,41 oraz 6,18-20", PzST 30 (2016) 191-214.

Nieścior, L., „Zachęta do ucieczki podczas prześladowań (Mt 10, 23a) w interpretacji patrystycznej”, Vox 36/65 (2016) 461-490.

Nowińska, J., „Pokój - zawsze dostępny? (Ap 1,4; 6,4)”, VV 30 (2016) 195-210.

Nowińska, J., „Miłosierdzie w Apokalipsie św. Jana - czy rzeczywiście nieobecne?”, Oblicza miłosierdzia w Biblii (red. J. Jaromin) (Bibliotheca Biblica; Wrocław: TUM 2016) 353-369.

Olszewska, K., „Elementy chrzcielne w Ap 2-3”, TiC 35/3 (2016) 39-53.

Ostański, P., „Eli, Eli, lema sabachthani (Mt 27,46). Aramejskie wyrażenia w greckim tekście Nowego Testamentu", PzST 30 215-226.

Ostański, P., „Ty będziesz nazywał się Kefas (J 1, 42). Kefas i inne aramejskie osobowe nazwy własne w greckim tekście Nowego Testamentu”, WPT 24/2 (2016) 7-20.

Pamuła, S., „I tam złóż Go w ofierze na jednym z pagórków, jak Ci wskażę” (Rdz 22,2). Wybrane metody egzegezy patrystycznej. Część druga”, Sem 37/4 (2016) 23-31.

Parchem, M., „Księga Ozeasza w Qumran: rękopisy biblijne (4Q78-79, 4Q82), cytaty w zwojach niebiblijnych (CD, 4Q163, 4Q177; 4Q434) i Peszer do Księgi Ozeasza (4Q166-167)”, CT 86/4 (2016) 139-172.

Parchem, M., „Modlitwa żydowskiej prozelitki w apokryficznym utworze Józef i Asenet (JzfAs 12-13)”, ,, Scrutamini Scripturas” (J 5,39). Księga jubileuszowa dla Księdza Biskupa Andrzeja W. Suskiego w 75. rocznicę urodzin (red. W. Chrostowski - D. Kotecki) (Ad Multos Annos 19; Warszawa: Stowarzyszenie Biblistów Polskich 2016) 315-341.

Parchem, M., „Pojęcie i funkcje «ducha Bożego» w pismach z Qumran”, Duch Święty (red. G.M. Baran - J. Królikowski - P. Łabuda) (Scripturae Lumen. Biblia i Jej Oddziaływanie 8; Tarnów: Biblos 2016) 111-126.

Parchem, M., „Zuzanna - wzór wierności Bogu i zachowania cnoty czystości (Dn 13)”, „Niewiastę dzielna kto znajdzie?" (Prz 31,10). Rola kobiet w biblijnej historii zbawienia (red. A. Kubiś K. Napora) (ABL 14; Lublin: Wydawnictwo KUL 2016) 211-222.

Parchem, M., „Biblijne korzenie legendy o smoku wawelskim, czyli podanie o całożercy z «Kroniki polskiej» Wincentego Kadłubka i późniejszych polskich przekazów kronikarskich w relacji do «Opowiadania o wężu» z Księgi Daniela (Dn 14,23-27)”, StGd 38 (2016) 17-48.

Parchem, M., „Księga Ozeasza w Qumran: rękopisy biblijne (4Q78-79, 4Q82), cytaty w zwojach niebiblijnych (CD, 4Q163, 4Q177; 4Q434) i peszer do Księgi Ozeasza (4Q166-167)”, CT 86/4 (2016) 139-171.

Piekarz, D., „«A światłość w ciemności świeci...» Konfrontacja światłości z ciemnością w Ewangelii Janowej”, $V V 29$ (2016) 251-269.

Pawłowski, Z., „Bóg i tożsamość Mojżesza. Lektura narracyjna Exodus 2,1-3,15”, BibAn 7/2 (2017) 187-205.

Piela, M., „Pierwsze wydanie Biblii Tysiąclecia w porównaniu z wydaniami późniejszymi”, Biblia Tysiąclecia jako wyzwanie. Język - kultura - duchowość (red. M. Pawlik) (Kraków: Wydawnictwo Benedyktynów Tyniec 2016) 129-146.

Pietkiewicz, R., „Hebraica Veritas w «Biblii brzeskiej»”, Studia Judaica 18/1 (2015) 197-222.

Pietkiewicz, R., „The Millennium Bible (1965-2015)”, PJBR 15/1 (2016) 5-17.

Pietkiewicz, R., „Wkład opactwa benedyktynów tynieckich w powstanie Biblii Tysiąclecia”, Biblia Tysiąclecia jako wyzwanie. Język - kultura - duchowość (red. M. Pawlik) (Kraków: Wydawnictwo Benedyktynów Tyniec 2016) 147-169.

Pikor, W., „Dynamika «przymierza pokoju» w Księdze Ezechiela”, VV 30 (2016) 53-78. 
Pilarczyk, K., „Dzieje Apostolskie a początki Kościoła. Wokół problemu datacji dzieła Łukasza”, ZNSBP 13 (2016) 369-390.

Popko, Ł., „Światło zwycięskie, światło odrzucone. Motyw światła w Iz 1-39”, VV 29 (2016) 117-148.

Pikor, W., „«Nawróćcie się do Pana» (Oz 14,3). Nawrócenie jako istota relacji Boga z człowiekiem”, CT 86/4 (2016) 63-76.

Pilarczyk, K., „Dokument Stolicy Apostolskiej w pół wieku po «Nostra aetate»”, WPT 1 (2016) 67-88.

Pilarczyk, K., „Dzieje Apostolskie a początki Kościoła”, ZNSBP 13/13 (2016) 369-390.

Pilarczyk, K., „Jan Paweł II i Stolica Apostolska wobec Żydów i judaizmu: polityczny i aksjologiczny aspekt dialogu", Czynnik religijny w polityce wewnątrzpaństwowej i międzynarodowej na przełomie drugiego i trzeciego tysiaclecia (red. M. Marczewska-Rytko) (Lublin: Wydawnictwo UMCS 2016) 75-84.

Pilarczyk, K., „Mojżesz Schorr 1874-1941”, Portrety uczonych. Profesorowie Uniwersytetu Warszawskiego. II. 1915-1945. II/2. M-Ż (red. P. Salwa-A.K. Wróblewski) (Warszawa: Uniwersytet Warszawski 2016) 695-699.

Pilarczyk, K., „Przebaczenie w judaizmie. W perspektywie rytuału święta Jom Kippur”, Paedagogia Christiana 37/1 (2016) 43-66.

Piotrkowska-Dańkowska, M., „«O jak piękna jesteś, jakże wdzięczna, umiłowana, pełna rozkoszy!» (Pnp 7,7). Od estetyki do ontologii. Symbolika Pnp 7,1-6”, Symbolika ciała w Starym Testamencie (red. A. Kuśmirek) (Warszawa: Wydawnictwo UKSW 2016) 271-291.

Piotrkowska-Dańkowska, M., „Chrystologiczny wymiar Iz 53,1-5”, StKKot 24 (2017) 41-54.

Piotrkowska-Dańkowska, M., „Przestrzenie inspiracji biblijnych w literaturze”, Fides, Ratio et Patria. Studia Toruńskie 6 (2017) 89-104.

Piotrkowska-Dańkowska, M. - Szetela, M., „Funkcja wybranych motywów w «Pieśni nad Pieśniami»”, Wizualizacja informacji w humanistyce (red. M. Kowalska - V. Osińska) (Toruń: Wydawnictwo UKSW 2017).

Piwowar, A., „Firmament i ciała niebieskie świadkami Boga (Syr 43,1-12)”, BibAn 7/1 (2017) 5-48.

Piwowar, A., „Jezus zmartwychwstał czy został obdarzony zmartwychwstaniem? Interpretacja

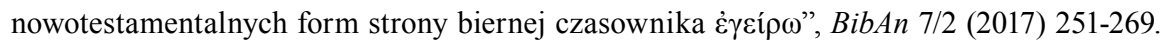

Piwowar, A., „«Podnieś się i rzuć się w morze!» (Mk 11,23/Mt 21,21). Rzecz o powszechnym błędzie w thumaczeniach polskich i jego teologicznych konsekwencjach”, BPTh 9/2 (2016) 145-167.

Piwowar, A., „Mędrzec - ideał człowieka poszukującego mądrości (Syr 14,20-15,10). Część I: Działanie mędrca (Syr 14,20-27)", BibAn 6/2 (2016) 183-225.

Piwowar, A., „Mędrzec - ideał człowieka poszukującego mądrości (Syr 14,20-15,10). Część II: Działanie mądrości (Syr 15,1-10)", BibAn 6/3 (2016) 357-417.

Piwowar, A., „Uczony w Piśmie - ideał człowieka poszukującego mądrości (Syr 38,24; 39,1-11)”, BibAn 6/4 (2016) 527-600.

Piwowar, A., „Zdobycie mądrości według Syracha (Syr 6,18-37). Część III: Środki konieczne do zdobycia mądrości (6,32-37)", BibAn 6/1 (2016) 73-105.

Podeszwa, P., „«Dusze ściętych dla świadectwa Jezusa i dla Słowa Bożego» (Ap 20,4). Kościół prześladowany - męczennicy i prześladowcy według Apokalipsy św. Jana”, „Milujcie waszych nieprzyjaciót” Mt 5,44. Chrześcijanie wobec prześladowań (red. C. Korzec) (Szczecin: Zapol 2016) 199-218.

Podeszwa, P., „Gościnność wobec «obcych braci» w świetle 3J”, BPTh 9/2 (2016) 71-85.

Poniży, B., „Metafory związku mądrości z Bogiem”, „Scrutamini Scripturas” (J 5,39). Księga jubileuszowa dla Księdza Biskupa Andrzeja W. Suskiego w 75. rocznicę urodzin (red. W. Chrostowski - D. Kotecki) (Ad Multos Annos 19; Warszawa: Stowarzyszenie Biblistów Polskich 2016) 370-376. 
Poniży, B., „Uosobiona Mądrość w Sophia Salomonos (7,22-8,1)”, ZNSBP 13 (2016) 391-400.

Pudełko, J., „The (Apparent) Absence of Women in the Praise of the Ancestors (Sir 44-49)”, BibAn 6/1 (2016) 107-126.

Pudełko, J.J., „Użycie terminu éleos («miłosierdzie») w Pochwale ojców (Syr 44-49)”, WStT 29/1 (2016) 66-81.

Pudełko, J., „Dlaczego Adam zamyka Pochwałę Ojców (Syr 44-49)?”, BibAn 7/4 (2017) 441-457.

Rakocy, W., „Pytanie o klucz do teologii apostoła Pawła”, CT 86/1 (2016) 41-60.

Rambiert-Kwaśniewska, A., „Zrozumieć Pawłowe miłosierdzie. Studium semantyczne terminu oiktirmos w listach Pawła z Tarsu", Oblicza miłosierdzia w Biblii (red. J. Jaromin) (Bibliotheca Biblica; Wrocław: TUM 2016) 317-337.

Rosik, M., „1 Kor 1,22-25”, Biblia w liturgii Mszy Świętej. Wielki Post (red. A. Paciorek - F. Mickiewicz) (W Drodze do Emaus 2; Częstochowa: Edycja Świętego Pawła 2016) 139-141.

Rosik, M., „1 Kor 10,1-6.10-12”, Biblia w liturgii Mszy Świętej. Wielki Post (red. A. Paciorek F. Mickiewicz) (W Drodze do Emaus 2; Częstochowa: Edycja Świętego Pawła 2016) 148-150.

Rosik, M., „Est-ce que dans les années 70/71 après Jésus-Christ Fiscus Iudaicus eut une influence sur la séparation des chemins du judaïsme et du christianisme? Etude historique et théologique", Meeting at the Borders. Studies Dedicated to Professor Wtadystaw Duczko (red. J. Popielska-Grzybowska - J. Iwaszczuk) (Acta Archeologica Pultuskiensia 5, Pułtusk: Pułtusk Academy of Humanities 2016) 201-213.

Rosik, M., „Gdy światło zmaga się z ciemnością. Symbolika światła w Mt 28,1-10”, VV 29 (2016) 227-250.

Rosik, M., „Grecki motyw wędrówki cyklicznej w Ewangelii św. Łukasza”, Piękna dama teologia. Księga jubileuszowa dedykowana Księdzu Profesorowi Romanowi E. Rogowskiemu (red. W. Wołyniec - J. Froniewski) (Wrocław: Papieski Wydział Teologiczny 2016) 359-368.

Rosik, M., „«Jeder, der dies von ihm erhofft, heiligt sich, so wie Er heilig ist» (1 Joh 3,3). Die Theologie der Hoffnung bei Johannes", Oblicza miłosierdzia w Biblii (red. J. Jaromin) (Bibliotheca Biblica; Wrocław: TUM 2016) 339-352.

Rosik, M., „Jezus z biczem w ręku”, ŻD 89 (2017) 29-37.

Rosik, M., „Judasz - motywy zdrady i bezdroża żalu”, ŻD 90 (2017) 5-15.

Rosik, M., „Męczeństwo wyznaniem wiary w Zmartwychwstanie”, ŻD 86 (2016) 51-59.

Rosik, M., „Niedziela za sobotę”, ŻD 87 (2016) 13-21.

Rosik, M., „Piekło - niebo. Bóg miłosierny czy sprawiedliwy?”, W Drodze 521/1 (2017) 36-44.

Rosik, M., „Przypowieść w literaturze greckiej i rzymskiej”, BKK 53 (2016) 14.

Rosik, M., „Przypowieść w Starym Testamencie i apokryfach”, BKK 53 (2016) 15-16.

Rosik, M., „Wspólnota w Qumran, pierwsi chrześcijanie i szkielet Jana Chrzciciela”, BKK 55 (2017) 6-13.

Rosik, M., „Zmartwychwstanie - historia i dzień dzisiejszy”, EE 13-14 (2016) 25-26.

Rucki, M., „«I nie bądź niewierzącym»: żydowskie rozumienie uzasadnionej wiary”, WPT 23/1 (2015) 85-98.

Rucki, M., „Sześć dni stworzenia - Heksaemeron”, TiC 33/1 (2016) 85-106.

Rucki, M., „Uzdrowienie niewidomego - podwójny dowód boskości Jezusa Chrystusa”, WPT 24/2 (2016) 23-37.

Rucki, M. - Moses, M.S. - Abdalla, M. - Benyamin, A., „Miłosierdzie Boże w tradycji judaizmu i Kościołów Wschodu", Oblicza miłosierdzia w Biblii (red. J. Jaromin) (Bibliotheca Biblica; Wrocław: TUM 2016) 371-404.

Siemieniec, T., „«Ojcze nasz» jako modlitwa Chrześcijan i Żydów? Modlitwa Pańska w kontekście literatury i teologii żydowskiej”, KStT 15 (2016) 199-222. 
Siemieniec, T., „The Concept of Judgment according to Rev 11:15-18”, BibAn 7/1 (2017) 87-106.

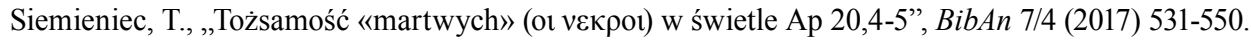

Sienkiewicz, E., „Bóg - Ojciec miłosierny w orędziu Jezusa o Królestwie Bożym”, StPar 26 (2016) 171-188.

Siepsiak, J., „Samarytanka u studni”, ŻD 88 (2016) 11-13.

Sieroń, R.B., „Od eros do agape. Pedagogia miłości w starotestamentalnej Pieśni nad Pieśniami w świetle badań interdyscyplinarnych", SiR 43 (2/2015).

Sikora, A.R., „Przekłady tekstów biblijnych z języków greckiego i hebrajskiego na kaszubski”, Omnia in manus Tuas. XXV-lecie istnienia Prowincji św. Franciszka z Asyżu Zakonu Braci Mniejszych $w$ Polsce (red. F.T. Janka) (Poznań: WT UAM 2016) 89-104.

Sikora, A.R., „Teologia chrztu w Ewangelii według św. Jana (J 3,1-21; 4,1-30; 9,1-39; 19,34). Próba syntezy", Chrzest Polski 966-2016. Ujęcie interdyscyplinarne (red. B. Kochaniewicz) (Poznań: WT UAM 2016) 17-32.

Sikora, A.R., „«W domu Ojca Mego mieszkań jest wiele» (J 14,2). Perspektywa chrześcijańskiej nadziei”, BPTh 9/4 (2016) 99-114.

Siwek, K., „Honor dziedziczenia w antropologicznokulturowej lekturze (Mk 10,17-22)”, StBob 3 (2016).

Siwek, K., „«Moje serce było rozgoryczone, a w nerkach odczuwałem dotkliwy ból» (Ps 73,21). Kompetencje semantyczne hebrajskich leksemów „k lāyōt” i „lēb” oraz ich aplikacja w Septuagincie", Symbolika ciała w Starym Testamencie (red. A. Kuśmirek) (Warszawa: Wydawnictwo UKSW 2016) 209-228.

Slawik, J., „Wczesny i późny biblijny język hebrajski: o możliwościach chronologicznego wyjaśniania różnic językowych w Biblii Hebrajskiej”, RT ChAT 4 (2016) 497-522.

Słowak, K., „«Od cudownego połowu ryb do pracy apostolskiej w świecie». Orędzie teologiczne J 21,1-14”, KStT 15 (2016) 343-361.

Sperling, S., „Tajemnica Antychrysta. Refleksja nad zagadnieniem od epoki Ojców Kościoła do czasów współczesnych”, StEł 19/1 (2017) 61-72.

Stasiak, S., „Bóg okazuje miłosierdzie komu chce”, Oblicza miłosierdzia w Biblii (red. J. Jaromin) (Bibliotheca Biblica; Wrocław: TUM 2016) 261-273.

Stefański, J., „«Rise, take the child and his mother, flee to Egypt” (Matt 2,13). But why to Egypt?”, TiC 28/4 (2014) 163-184.

Stefański, J., „Dwaj synowie Dawida i dwie świątynie: dom świętego Józefa jako przejście od Świątyni Jerozolimskiej do świątyni katolickiej”, $A K$ 167/2 (2016) 211-230.

Stefański, J., „Średniowieczna egzegeza karaimska na przykładzie wybranych zagadnień z komentarza Jefeta ben Eliego do Księgi Ozeasza”, CT 86/4 (2016) 205-222.

Strojny, J., „Miłosierdzie Boże drogą do zjednoczenia w Chrystusie”, WStT 29/1 (2016) 48-64.

Strzałkowska, B., „Księga Ozeasza w Septuagincie”, CT 86/4 (2016) 77-102.

Stypułkowska, B., „Chrzest w katechezie biblijnej kandydatów do bierzmowania”, Rozbudzić pamięć chrztu. Chrzest w historii, teologii i katechezie (red. R. Ceglarek - M. Borda) (Częstochowa: Częstochowskie Wydawnictwo Archidiecezjalne Regina Poloniae 2016) 301-320.

Stypułkowska, B., „Biblijna katecheza o miłosierdziu skierowana do dziewic konsekrowanych. Przyczynek do formacji stałej”, Oblicza miłosierdzia w Biblii (red. J. Jaromin) (Bibliotheca Biblica; Wrocław: TUM 2016) 97-122.

Stypułkowska, B., „Chrystus miłosierny w katechezie biblijnej”, Bądźcie świadkami miłosierdzia (red. R. Ceglarek - A. Kuliberda) (Częstochowa: Częstochowskie Wydawnictwo Archidiecezjalne Regina Poloniae 2017) 195-211. 
Stypułkowska, B., „Król Dawid i jego Potomek jako zagadnienie katechetyczne”, CzST 44 (2016) 161-186.

Szamocki, G., „Bóg Izraela - wojownik czy miłośnik pokoju?”, VV 30 (2016) 17-41.

Szmajdziński, M., „«Miłosierny i łaskawy...» Funkcjonowanie synajskiego wyznania wiary (Wj 34,6-7) w Zbiorze Dwunastu Proroków”, Oblicza miłosierdzia w Biblii (red. J. Jaromin) (Bibliotheca Biblica; Wrocław: TUM 2016) 71-96.

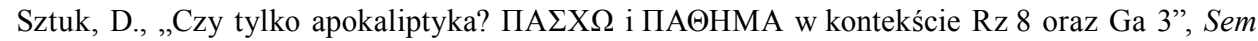
$37 / 1$ (2016) 15-25.

Szymik, S., „Radość pielgrzymowania. Ps 122 w perspektywie historycznej i teologicznej”, Radość Ewangelii. Biblijne źródła chrześcijańskiej radości (red. A. Zawadzki) (ABL 12; Lublin: Wydawnictwo KUL 2016) 139-149. Przedruk: Łódzkie Studia Teologiczne 25/1 (2016) 171-182.

Szymik, S., „Jezus jako gość w świetle ewangelii kanonicznych”, BPTh 9/2 (2016) 125-141.

Targoński, M., „Światłość Bożego mieszkania według pism qumrańskich w kontekście tradycji biblijnej i apokryficznej”, VV 29 (2016) 149-171.

Terka, M., „«Potestas nocendi» w świetle komentarzy św. Augustyna do Księgi Hioba 1-2”, Vox 36/65 (2016) 653-681.

Tobola, Ł., „Imiona królów judzkich - kilka spostrzeżeń”, BibAn 6/4 (2016) 601-610.

Tomaszewski, T., „Nowotestamentalne miłosierdzie na język polski tłumaczone”, Rocznik Skrzatuski 4 (2016) 13-29.

Tronina, A., „Homo viator”, Via Crucis. Droga Krzyżowa. Historia i duchowość nabożeństwa oraz antologia współczesnych rozważań (red. R.S. Pujsza) (Warszawa: Żywe Słowo 2017) 903-907.

Tronina, A., „«Magnificat» - duchowy portret Maryi i Kościoła, Liturgia uświęcenia czasu - rozumieć, aby lepiej uczestniczyć. Wyktad liturgii godzin (red. J. Hadalski) (Poznań: Hlondianum 2017) 168-179.

Tronina, A., „Maryja, Matka miłosierdzia”, Msza Święta 72/5 (2016) 10-13.

Tronina, A., „Miłosierdzie Boże w Psalmach Salomona”, ,Scrutamini Scripturas” (J 5,39). Księga jubileuszowa dla Księdza Biskupa Andrzeja W. Suskiego w 75. rocznicę urodzin (red. W. Chrostowski - D. Kotecki) (Ad Multos Annos 19; Warszawa: Stowarzyszenie Biblistów Polskich 2016) 430-445.

Tronina, A., „Pośrednik w sporze Hioba z Bogiem”, CzST 44 (2016) 187-199.

Tronina, A., „Urodziny i imieniny Matki”, Msza Święta 72/9 (2016) 2-4.

Turek, W., „«Exempla» starotestamentalnych kobiet w interpretacji «Prima Clementis»”, Vox 36/66 (2016) 10-23.

Twardziłowski, T., „Polecenie panowania nad stworzeniem (Rdz 1,26-28) w ekologicznej hermeneutyce Biblii", CT 86I/1 (2017) 5-24.

Uciecha, A., „Adam i Ewa we wschodnio-syryjskiej egzegezie Iszodada z Merw (Rdz 2,21-24). Stan badań, komentarz i przekład", ŚSHT 49/2 (2016) 302-310.

Urbański, J.P., „«Bądźcie miłosierni, jak Ojciec wasz jest miłosierny» (Łk 6, 36) jako wiodąca idea Nadzwyczajnego Roku Miłosierdzia”, Oblicza miłosierdzia w Biblii (red. J. Jaromin) (Bibliotheca Biblica; Wrocław: TUM 2016) 21-40.

Wajda, A.M, „Sztuka budowlana w czasach Biblii”, StLeo 9 (2016) 51-66.

Wańczyk, P., „Wychowawcze wskazówki dla rodziców w Corpus Paulinum”, RBL 69/3 (2016) 253-271.

Wejman, H., „Przypowieść o bogatym młodzieńcu (Mk 10, 17-22). Duchowy wymiar miłosierdzia świadczonego", StPar 26 (2016) 239-247.

Węgrzyn, A., „Kim jest ten, który i grzechy odpuszcza. Analiza narracyjna Łk 7,36-50”, ZNSBP 13 (2016) 401-418. 
Wiater, E., „Jezus uzdrawiający w szabat”, $̇ \dot{D} 87$ (2016) 23-31.

Wilk, J., „Personalia w Drugim Liście do Tymoteusza 4,9-15”, CT 87/1 (2017) 49-74.

Wiszowaty, E., „Dzień Pański jako determinanta przepowiadania homilijnego”, StEł 18/4 (2016) 408-417.

Wojtyła, W., „«Z drzewa poznania dobra i zła nie wolno ci jeść» $(R z 2,17)$ - teoria prawa naturalnego", $Z F K 61$ (2016) 50-56.

Wons, K., „Tryptyk oblicza Boga Miłosierdzia (Łk 15)”, Oblicza miłosierdzia w Biblii (red. J. Jaromin) (Bibliotheca Biblica; Wrocław: TUM 2016) 143-169.

Wronka, S., „Sens i znaczenie Bramy Miłosierdzia”, Miłosierdzie w praktyce duszpasterskiej. Referaty z sympozjum w Sanktuarium Bożego Miłosierdzia, Kraków-Lagiewniki, 7 kwietnia 2016 r. (red. M. Gilski - F. Ślusarczyk) (Kraków: Wydawnictwo Świętego Stanisława BM 2016) 23-44.

Wronka, S., „Podporządkowanie kobiety mężczyźnie w Nowym Testamencie - ślad epoki czy stała norma?", ZNSBP 13 (2016) 419-435.

Wronka, S., „Pismo Święte narzędziem dialogu z Bogiem”, RBL 69/4 (2016) 355-375.

Wygralak, P., „Jezus Chrystus i pokój. Refleksje św. Augustyna z Hippony”, VV 30 (2016) 259-276.

Zawadzki, A., „Izrael jako mesjańska Mądrość i jej świadectwo pośród narodów w Iz 55,3-5. Studium egzegetyczo-historyczne", CT 86/2 (2016) 5-50.

Zawadzki, A., ,Jahwe - „szybki śwadek” w M1 3,5b na tle literatury międzytestamentalnej i rabinicznej", BibAn 6/3 (2016) 325-356.

Zawadzki, A., „Nowe tłumaczenie i interpretacja Iz 55,3-5. Studium egzegetyczno-historyczne”, BibAn 7/1 (2017) 49-85.

Zawadzki, R., „Cypr - wyspa ewangelicznej siejby poprzez wieki (część 1)”, WPT 24/2 (2016) 39-52.

Zbroja, B., „Modlitwy świętych Apokalipsy (Ap 5,8 i 8,3n)”, StLeo 9 (2016) 79-88.

Ziaja, K., „Naśladowanie Boga w Jego miłosierdziu (Łk 6, 36-38)”, Oblicza miłosierdzia w Biblii (red. J. Jaromin) (Bibliotheca Biblica; Wrocław: TUM 2016) 123-142.

Zieliński, M., „Światło jako symbol mądrości i Prawa w Księdze Mądrości”, VV 29 (2016) 99-115.

Zieliński M., „La morte nel libro della Sapienza”, BibAn 7/3 (2017) 307-322.

Zielonka, I., „Powrót do początków”, Maryja Gwiazda Nowej Ewangelizacji. Teologia i duszpasterstwo (red. I. Zielonka) (Teresin: Wydawnictwo Ojców Franciszkanów Niepokalanów 2017) 9-14.

Zielonka, I., „Kerygmat Maryi - misyjna eksplozja Kościoła”, Maryja Gwiazda Nowej Ewangelizacji. Teologia i duszpasterstwo (red. I. Zielonka) (Teresin: Wydawnictwo Ojców Franciszkanów Niepokalanów 2017) 147-159.

Zielonka, I., „Biblijne podstawy macierzyństwa Maryi w porządku łaski”, Matka Boga i ludzi. Wybrane zagadnienia z mariologii (red. G. Bartosik - P. Warchoł) (Teresin: Wydawnictwo Ojców Franciszkanów Niepokalanów 2016) 11-24.

Zielonka, I., „Wyzwania Nowej Ewangelizacji. Aspekty kanoniczno-prawne”, Fides, quae de verbo nascitur et nutritur - Nauczycielskie zadanie Kościoła wobec 1050. rocznicy Chrztu Polski (red. J. Krajczyński - A. Domaszk) (Płock: Płocki Instytut Wydawniczy 2016) 49-89.

Zwijacz, E.N., „«Pan nieskory do gniewu, bogaty w miłosierdzie» (Lb 14, 18)”, Oblicza miłosierdzia w Biblii (red. J. Jaromin) (Bibliotheca Biblica; Wrocław: TUM 2016) 61-70.

Żurek, A., „Chrześcijanin «człowiekiem pokoju» (Ps 37,37) w tradycji Ojców Kościoła okresu przedkonstantyńskiego", $V V 30$ (2016) 213-229.

Żywica, Z., „Eklezja Mateusza - eschatologiczną «Resztą Izraela»?”, CT 86/1 (2016) 25-40.

Żywica, Z., „«Obrzezany» Grek i «prawdziwy» Żyd w świetle Rz 1,18-3,20”, CT 87/1 (2017) 25-48. 


\section{Część piąta: recenzje}

Adamczewski, B., rec. J.C. Poirier - J. Peterson (red.), Marcan Priority without Q. Explorations in the Farrer Hypothesis (Library of New Testament Studies 455; London - New York: Bloomsbury - T\&T Clark 2015), BibAn 6/2 (2016) 311-315.

Adamczewski, B., rec. R.K. MacEwen, Matthean Posteriority: An Exploration of Matthew's Use of Mark and Luke as a Solution to the Synoptic Problem (Library of New Testament Studies 501; London - New York: Bloomsbury - T\&T Clark 2015), BibAn 6/3 (2016) 513-517.

Bąk, T., rec. D. Muszytowska (red.), Patronka filologii. Rola Biblii w rozwoju edytorstwa, badań językoznawczych i translatorskich (Warszawa: Wydawnictwo UKSW 2015), VV 30 (2016) 329-336.

Bąk, T., rec. G. Ibba, Il Vangelo di Marco e l'impuro (Antico e Nuovo Testamento 22; Brescia: Morcelliana 2014), BibAn 6/1 (2016) 141-146.

Bąk, T., rec. M. Rosik, Kodeks Synajski. Biografia (Wrocław: Chronicon 2015), VV 29 (2016) 381-390.

Bergel, Ł., rec. S.J. Wood, The Alter-Imperial Paradigm. Empire Studies \& the Book of Revelation (Biblical Interpretation Series 140; Leiden - Boston: Brill 2016), BibAn 7/4 (2017) 579-582.

Biegas, M., rec. U. Dahmen, Psalmen- und Psalter-Rezeption im Fruhjudentum. Rekonstruktion, Textbestand, Struktur und Pragmatik der Psalmenrolle 11QPsa aus Qumran (Studies on the Texts of the Desert of Judah 49; Leiden - Boston: Brill 2003), BibAn 6/4 (2016) 695-698.

Chrostowski, W., rec. A.M. Wierzbicki, Szeroko otwierat drzwi Kościoła (Lublin: Gaudium 2016), CT 86/3 (2016) 238-244.

Chrostowski, W., rec. B. Strzałkowska (red.), Artefakty czasów biblijnych w Luwrze (Artefakty Czasów Biblijnych 2; Warszawa 2016), CT 86/4 (2016) 268-270.

Chrostowski, W., rec. E. Zolli, Nazarejczyk (tt. A.J. Katolo) (Gliwice: Fundacja Instytut Globalizacji 2015), CT 86/3 (2016) 231-238.

Chrostowski, W., rec. M. Cogan, Bound for Exile. Israelites and Judeans under Imperial Yoke. Documents from Assyria and Babylonia (A Carta Handbook; Tel Aviv 2013) CT 86/4 (2016) 263-268.

Chrostowski, W., rec. M. Małecki, Z Ziemi Świętej do Polski. Dzieje Bożogrobców. From Holy Land do Poland. The History of the Order of the Holy Sepulcre (Katowice: Drukarnia Archidiecezjalna w Katowicach 2013), CT 86/2 (2016) 209-212.

Chrostowski, W., rec. M. Rosik, Kościót a Synagoga (30-313 po Chr.). Na rozdrożu (Wrocław: Chronicon 2016), BibAn 7/3 (2017) 399-407.

Chrostowski, W., rec. P. Asolan, Il santo viaggio. Appunti di pastorale del pelegrinaggio, (Collana Strumenti 16; Città del Vaticano: Lateran University Press, 2013), CT 86/1 (2016) 231-235.

Chrostowski, W., rec. P. Calamatta, Maltese Plants in the Bible (The Millennium Chapel in Paceville; Malta: Peter Calamatta 2016), CT 87/1 (2017) 272-275.

Chrostowski, W., rec. R. Pietkiewicz, Biblia Polonorum. Historia Biblii w języku polskim. V. Biblia Tysiaclecia (1965-2015) (Poznań: Pallottinum 2015), CT 87/1 (2017) 265-272.

Chrostowski, W., rec. S. Surdykowska (red.), Orientalistyka. Rozważania o nauce (Warszawa: Wydawnictwo UW 2015), CT 86/2 (2016) 212-215.

Chrostowski, W., rec. We wszystkim Chrystus. O narodzie, Kościele, mediach i rodzinie z Biskupem Stanisławem Stefankiem TChr rozmawia Marzena Nykiel (Łomża: Spes 2015), CT 86/1 (2016) 235-242.

Darowski, Ł., rec. S.A. Hunt - D.F. Tolmie - R. Zimmermann (red.), Character Studies in the Fourth Gospel (WUNT 314; Tübingen: Mohr Siebeck 2013), BibAn 7/1 (2017) 163-168. 
Dąbek, T.M., rec. F. Mickiewicz SAC, Ewangelia według świętego Eukasza, rozdziały 1-11. Wstęp, przekład z oryginatu, komentarz (NKB.NT 3.1; Częstochowa: Edycja Świętego Pawła 2011); Ewangelia wedtug świętego Lukasza, rozdziały 12-24. Wstęp, przekład z oryginatu, komentarz (NKB.NT, 3.2; Częstochowa: Edycja Świętego Pawła 2012), RBL 69/1 (2016) 93-96.

Dziadosz, D., rec. U. Becker - H. Bezzel (red.), Rereading the relecture? The Question of (Post) chronistic Influence in the Latest Redactions of the Books of Samuel (Forschungen zum Alten Testament 2. Reihe 66; Tübingen: Mohr Siebeck 2014), BibAn 7/2 (2017) 271-276.

Jasinski, M., rec. H.-J. Fabry - U. Dahmen (red.), Theologisches Wörterbuch zu den Qumrantexten (Stuttgart: Kohlhammer 2011, 2013, 2016) I-III, BibAn 7/1 (2017) 149-155.

Jaworski, P., rec. K. Gniwek, Czynność symboliczna w księdze Jeremiasza jako forma prorockiego głoszenia Słowa Bożego. Studium Historyczno - Teologiczne Księgi Jeremiasza [sic!] (Przemyśl: Wydawnictwo Archidiecezji Przemyskiej 2016), VV 29 (2016) 371-380.

Kapera, Z., rec. A. Feldman, The Dead Sea Scrolls Rewritten Samuel and Kings. Texts and Commentary (Berlin - Boston: De Gruyter 2015), QChr 24 (2016) 81-83.

Kapera, Z., rec. A. Souter (red.), Compact Greek-English Lexicon of the New Testament (Peabody, Mass.: Hendrickson Publ. 2016), PJBR 16, 1/31 (2017) 99-100.

Kapera, Z., rec. D. Edelman - A. Fitzpatrick-McKinley (red.), Religion in the Achaemenid Empire (Tübingen: Mohr Siebeck, 2016), PJBR 15, $2 / 30$ (2016) 79-81.

Kapera, Z., rec. D.P. Moessner, Luke the Historian of Israel's Legacy, Theologian of Israel's 'Christ'(Berlin - Boston: De Gruyter 2016), PJBR 16, 1/31 (2017) 102-103.

Kapera, Z., rec. E. Yamauki - M.R. Wilson (red.), Dictionary of daily Life in Biblical \& Post-biblical Antiquity (Peabody, Mass.: Hendrickson Publ. 2015-2016) II-IV, PJBR 16, 1/31 (2017).

Kapera, Z., rec. G. Vermes, The True Herod (London: Bloomsbury 2014), QChr 24 (2016), 96-98.

Kapera, Z., rec. J.E. Taylor (red.) Palestine in the Fourth Century A.D. The Onomasticon by Eusebius of Caesarea (Jerusalem: Carta 2003 [Publ. 2015]), PJBR 15, 1/29 (2016) 120-121.

Kapera, Z., rec. K. Atkinson, Queen Salome. Jerusalem's Warrior Monarch of the First Century B.C.E. (Jefferson, N.C. - London: McFarland Publ. 2012), QChr 24 (2016) 77-81.

Kapera, Z., rec. K.H. Jobes (red.) Discovering the Septuagint. A Guided Reader (Grand Rapids: Kregel Publ. 2016), PJBR 16, 1/31 (2017) 61-62.

Kapera, Z., rec. L.-K. Ritmeyer, Jerusalem in the Year 30 A.D. (Jerusalem: Carta 2015), PJBR $16,1 / 31$ ( 2017) 89-91.

Kapera, Z., rec. L.-K. Ritmeyer, Jerusalem. The Temple Mount (Jerusalem: Carta 2015), PJBR $15,1 / 29$ (2016) 90-92.

Kapera, Z., rec. M. Avi-Yonah - S. Safrai - Z. Safrai, Understanding the Maccabeab Revolt 167 to 63 BCE (Jerusalem: Carta 2016), PJBR 16, 1/31(2017) 97-98.

Kapera, Z., rec. M. Avi-Yonah, Understanding the Life of Jesus. An Introductory Atlas (Jerusalem: Carta 2015), PJBR 16,1/31 (2017) 85-86.

Kapera, Z., rec. M. Goff - L.T. Stuckenbruck, Ancient Tales of Giants from Qumran and Turfan. Context, Traditions, and Influences (Tübingen: Mohr Siebeck 2016), QChr 24 (2016) 83-85.

Kapera, Z., rec. M. Hengel, Jesus und die Evangelien. Kleine Schriften V (Tübingen: Mohr Siebeck 2016), PJBR 16, 1/31 (2017) 101-102.

Kapera, Z., rec. P.H. Wright, Understanding Great People of the Bible. An Introductory Atlas to Biblical Biography (Jerusalem: Carta 2015), PJBR 16,1/31 (2017) 77-78.

Kapera, Z., rec. R.K. Harrison, Introduction to the Old Testament (Peabody, Mass.: Hendrickson Publ. 2016), PJBR 16, 1/31 (2017) 78-79. 
Kapera, Z., rec. R.S. Notley, Jerusalem. City of the Great King (Jerusalem: Carta 2016), QChr 24 (2016) 92-95.

Kapera, Z., rec. S.J. Joseph, Jesus and the Temple. The Crucifixion in Its Jewish Context (Cambridge: Cambridge University Press 2016), QChr 24 (2016) 85-88.

Kapera, Z., rec. S. Longosz (red.), Miscellanea Patristica. Księga jubileuszowa Księdza Profesora Wincentego Myszora, Vox 32/57 (2012); PJBR 15, 1/29 (2016) 136-139.

Kapera, Z., rec. S. Notley (red.), Josephus Carta's Illustrated the Jewish War. Translated from Greek by William Whiston (Jerusalem: Carta 2016), PJBR 16, 1/31 (2017) 86-89.

Kapera, Z., rec. S.W. Need, Jerusalem. Church of the Holy Sepulcre. An introduction \& Guide (Jerusalem: Carta 2016), PJBR 16,1/31 (2017) 105-106.

Kapera, Z., rec. S. Wachsmann, Understanding the Boat from the Time of Jesus. Galilean Seafaring (Jerusalem: Carta 2015), PJBR 16, 1/31 (2017) 91-92.

Kapera, Z., rec. U. Leibner - C. Hezser (red.), Jewish art in Its Late Antique Context (Tübingen: Mohr Siebeck 2016), PJBR 16, 1/31 (2017) 110-112.

Kapera, Z., rec. V.H. Matthews - D. C. Benjami, Old Testament Parallels. Laws and Stories from the Ancient Near East (Tübingen: Mohr Siebeck 2016), PJBR 15, 2/30 (2016) 86-88.

Kapera, Z., rec. W. Chrostowski - D. Kotecki (red.) „Scrutamini Scripturas” (J 5,39). Ksiega jubileuszowa dla Księdza Biskupa Andrzeja W. Suskiego w 75. rocznicę urodzin (Ad Multos Annos 19; Warszawa: Stowarzyszenie Biblistów Polskich 2016), PJBR 15, 2/30 (2016) 76-79.

Kapera, Z., rec. W.E. Popkes - G. Wurst (red.), Judasevangelium und Codex Tchacos (Tübingen: Mohr Siebeck 2012), PJBR 15, 1/29 (2016) 139-141.

Kapera, Z., rec. W.G. Lambert, Ancient Mesopotamian Religion and Mythology. Selected Essays (Mohr Siebeck: Tübingen 2016), PJBR 15, $2 / 30$ (2016) 81-84.

Kapera, Z., rec. W. Horbury, Jewish war under Trajan and Hadrian (Cambridge: Cambridge University Press 2015), PJBR 15, 1/29 (2016) 122- 125.

Kapera, Z., rec. W. Kardyś, Szatan w Starym Testamencie oraz w Judaizmie Drugiej Światyni (Lublin: Wydawnictwo KUL 2015), QChr 24 (2016) 88-92.

Klukowski, M., rec. J. Dvořáček, The Son of David in Matthew's Gospel in the Light of the Solomon as Exorcist Tradition (Wissenschaftliche Untersuchungen zum Neuen Testament 2. Reihe 415; Tübingen: Mohr Siebieck 2016), BibAn 7/2 (2017) 277-280.

Kowalski, M., rec. J.W. Aernie, Is Paul also among the Prophets? An Examination of the Relationship between Paul and Old Testament Prophetic Tradition in 2 Corinthians (LNTS 47; London: T\&T Clark 2012), BibAn 7/3 (2017) 375-379.

Kowalski, K., rec. W. Linke CP, Literacka ojczyzna Tobiasza. Tło kulturowe Tb jako klucz teologicznej lektury księgi (Lingua Sacra. Monografie 2; Warszawa: Verbinum 2013), BibAn 6/3 (2016) 509-512.

Kowalski, M., rec. L. Doering, Ancient Jewish Letters and the Beginnings of Christian Epistolography (WUNT I/298; Tubingen: Mohr Siebeck 2012), BibAn 7/4 (2017) 551-555.

Kowalski, M., rec. M.T. Finney, Honour and Conflict in the Ancient World. 1 Corinthians in Its Greco-Roman Social Setting (LNTS 46; London - New York: T\&T Clark 2012), BibAn 7/4 (2017) 557-561.

Kręcidło, J., rec. E. Kobel, Dining with John: Communal Meals and Identity Formation in the Fourth Gospel and its Historical and Cultural Context (Biblical Interpretation Series 109; Leiden - Boston: Brill 2011), BibAn 6/3 (2016) 505-507.

Kręcidło, J., rec. K.B. Larsen, Recognizing the Stranger: Recognition Scenes in the Gospel of John (Brill's Paperback Collection; Leiden - Boston: Brill 2012), BibAn 6/4 (2016) 715-717. 
Kubiś, A., rec. C. Keith, Jesus' Literacy. Scribal Culture and the Teacher from Galilee (Library of New Testament Studies 413 - Library of Historical Jesus Studies 8; London et al.: Bloomsbury 2013), BibAn 6/4 (2016) 707-714.

Kubiś, A., rec. D. Muszytowska, Etos chrześcijańskiej wspólnoty. Socjoretoryka Listu Jakuba (Warszawa: Wydawnictwo UKSW 2016), VV 30 (2016) 337-346.

Kubiś, A., rec. J.M. Czerski, Ewangelia i Listy św. Jana. Wprowadzenie literackie, historyczne i teologiczne (Opolska Biblioteka Teologiczna 156; Opole: Redakcja Wydawnictw Wydziału Teologicznego Uniwersytetu Opolskiego 2016), VV 29 (2016) 365-370.

Kubiś, A., rec. L. Gasparro, Simbolo e narrazione in Marco. La dimensione simbolica del secondo Vangelo alla luce della pericope del fico di Mc 11,12-25 (Analecta Biblica 198; Roma: Gregorian \& Biblical Press 2012), Resovia Sacra 23 (2016) 477-484.

Kubiś, A., rec. M. Grilli, Il Vangelo secondo Giovanni. Elementi di introduzione e teologia (Biblica; Bologna: Edizioni Dehoniane Bologna 2016), BibAn 7/3 (2017) 389-392.

Kubiś, A., rec. R. Bartnicki, Dzieje głoszenia Słowa Bożego. Jezus i najstarszy Kościót (Kraków: Petrus 2015), VV 29 (2016) 357-364.

Kubiś, A., rec. W.R. Bynum, The Fourth Gospel and the Scriptures. Illuminating the Form and Meaning of Scriptural Citation in John 19,37 (Supplements to Novum Testamentum 144; Leiden - Boston, MA: Broll 2012), BibAn 7/3 (2017) 381-387.

Kucharski, J., rec. H. Witczyk, Miłosierdzie Pana. Od wieków i na wieki (Kielce: Jedność 2015), ZFK 3/63 (2016).

Kucharski, J., rec. R.B. Sieroń - S. Brzeski, Sandomierskie spotkania z Bibliq. Polskie Dzieło Biblijne im. Św. Jana Pawła II w Diecezji Sandomierskiej 2005-2016 (Sandomierz - Stalowa Wola: KUL Wydział Zamiejscowy Nauk o Społeczeństwie 2016), ZFK 2/66 (2017) 113-116.

Lemański, J., rec. J. Huddleston, Eschatology in Genesis (FAT 2. Reihe 57; Tubingen: Mohr Siebeck 2012), BibAn 6/1 (2016) 131-139.

Lemański, J., rec. R. Albertz, Exodus 19-40 (Zürcher Bibelkommentare AT 2.2; Zürich: Theologischer Verlag Zürich 2015), BibAn 6/3 (2016) 495-500.

Lipiński, E., rec. H. Gzella, A Cultural History of Aramaic: From the Beginnings to the Advent of Islam (Handbook of Oriental Studies / Handbuch der Orientalistik. Section 1. The Near and Middle East 111; Leiden - Boston: Brill 2015), BibAn 6/2 (2016) 289-295.

Lipiński, E., rec. I. Kalimi - S. Richardson (red.), Sennacherib at the Gates of Jerusalem. Story, History and Historiography (Culture and History of the Ancient Near East 71; Leiden - Boston: Brill 2014), BibAn 6/1 (2016) 147-149.

Majewski, M., rec. T. Niemas, Perspektywa eschatologiczna proegzystencji wierzacych $w$ przekazie Pisma Świętego (Bibliotheca Biblica; Wrocław: TUM 2016), BibAn 7/1 (2017) 181-184.

Mazur, R., rec. S. Jankowski, „Co Bóg złączył...”. Geneza i znaczenie klauzul Mateuszowych. Studium egzegetyczno-historyczne (Rozprawy i Studia Biblijne 46; Warszawa: Vocatio 2015), BibAn 6/4 (2016) 699-706.

Mielcarek, K., rec. A. Paciorek, Jezus z Nazaretu. Czasy i wydarzenia (Częstochowa: Edycja Świętego Pawła 2015), BibAn 6/2 (2016) 307-310.

Mielcarek, K., rec. G.O. Holmås, Prayer and Vindication in Luke-Acts. The Theme of Prayer within the Context of the Legitimating and Edifying Objective of the Lukan Narrative (Library of New Testament Studies 433; New York - London: T\&T Clark 2011), BibAn 7/1 (2017) 157-162.

Mielcarek, K., rec. M.S. Rindge, Jesus' Parable of the Rich Fool: Luke 12:13-34 among Ancient Conversations on Death and Possessions (Society of Biblical Literature. Early Christianity and Its Literature 6; Atlanta: Society of Biblical Literature 2011), BibAn 6/4 (2016) 719-723. 
Mielcarek, K., rec. P. Łabuda, Abyś się przekonat o stuszności nauk. Lectio divina. Przypowieści z Ewangelii św. Łukasza (W kręgu Słowa 16; Tarnów: Biblos 2016), VV 30 (2016) 325-328.

Napora, K., rec. D. Iwański, Księga Lamentacji. I. Jahwe zniszczyt. Rozdz. 1-2. Wstęp, przekład z oryginatu, komentarz (Torun: Wydawnictwo UMK 2015), VV 30 (2016) 317-323.

Napora, K., rec. K. Bardski, Alegoryczno-symboliczna interpretacja Biblii (Kraków: Petrus 2016), VV 29 (2016) 349-356.

Oracz, A., rec. L.R. Zelyck, John among the Other Gospels. The Reception of the Fourth Gospel in the Extra-Canonical Gospels (Wissenschaftliche Untersuchungen zum der Neuen Testament II/ 347; Tubingen: Mohr Siebeck 2013), BibAn 7/3 (2017) 409-411.

Pietkiewicz, R., rec. F. Posset, Johann Reuchlin (1455-1522). A theological Bibliography (Arbeiten zur Kirchengeschichte 129; Berlin - Boston: De Gruyter 2015), BibAn 7/3 (2017) 393-398.

Pietrzak, J., rec. N.G. Piotrowski, Mathew's New David and the End of Exile. A Socio Rhetorical Study of Scriptural Quotations (Supplements to Novum Testamentum 170; Leiden -Boston: Brill 2016), BibAn 7/4 (2017) 567-572.

Pilarczyk, K., rec. M. Rosik, Kościół a Synagoga (30-313 po Chr.). Na rozdrożu (Wrocław: Chronicon 2016), BibAn 7/2 (2017) 297-303.

Pilarczyk, K., rec. R. Pietkiewicz, Biblia Polonorum. Historia Biblii w j. Polskim. I. Od początku do 1638 roku (Papieski Wydział Teologiczny we Wrocławiu; Poznań: Pallotinum 2016), BibAn $7 / 4$ (2017) 563-566.

Piwowar, A., rec. C. Rico - E. Vicart - P. Morales - D. Martinez, Mó̀ıs. Polis. Parlare il greco antico come una lingua viva (Cinisello Balsamo: Edizioni San Paolo 2010), BibAn 6/1 (2016) 159-166.

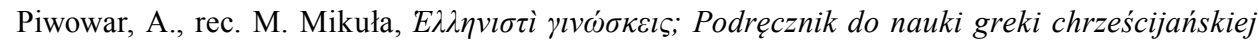
(Warszawa: Wydawnictwo Naukowe Sub Lupa 2013), BibAn 6/2 (2016) 297-305.

Piwowar, A., rec. T. Muraoka, A Syntax of Septuagint Greek (Leuven - Paris - Bristol, CT: Peeters 2016), BibAn 7/2 (2017) 291-295.

Podeszwa, P., rec. D. Kotecki, Con Gesù nella barca (Mc 4,35-41; 6,45-52; 8,13-21). Contributo allo studio del discepolato nel Vangelo di Marco (Toruń: Wydawnictwo Naukowe UMK 2015), $\mathrm{TiC} 35 / 3$ (2016) 227-230.

Podeszwa, P., rec. T. Tułodziecki, Tożsamość nowego Izraela w Księdze proroka Zachariasza. Studium egzegetyczno-teologiczne Za 1-8, (Scripta Theologica Thoruniensia 33, Toruń: Wydawnictwo UMK 2014), BPTh 9/1 (2016) 171-177.

Stefański, J., rec. E. Eynikel - T. Nicklas (red.), Samson: Hero or Fool? The Many Faces of Samson (Leiden - Boston, MA; Brill 2014), BibAn7/2 (2017) 281-285.

Rosik, M., rec. T. Niemas, Perspektywa eschatologiczna proegzystencji wierzacych w przekazie Pisma Świętego (Bibliotheca Biblica; Wrocław: TUM 2016), VV 30 (2016) 347-350.

Rosik, M., rec. W. Pikor, Rola ziemi w przymierzu Boga z Izraelem. Studium historyczno-teologiczne Ksiegi Ezechiela (Lublin: Wydawnictwo KUL 2013), WPT 24/1 (2016) 168-170.

Urbanek, B., rec. Ch.W. Skinner, Characters and Characterisation in the Gospel of John (The Library of New Testament Studies 461; London - New York: Bloomsbury T\&T Clark 2013), BibAn 7/4 (2017) 573-578.

Zaklukiewicz, T., rec. B. Poniży, Księga Mądrości na dziś (Manet Questio 26; Poznań: Uniwersytet im. Adama Mickiewicza 2014), Sem $37 / 3$ (2016) 238-239. 


\section{Część szósta: hasła słownikowe}

Chrostowski, W., „Izrael. 2. Naród Izraela”, NSTB 278-280.

Chrostowski, W., „Judeochrześcijaństwo”, NSTB 392-395.

Chrostowski, W., „Kobieta. I. W judaizmie”, NSTB 427-429.

Chrostowski, W., „List rozwodowy”, NSTB 461-463.

Chrostowski, W., „Matriarchinie”, NSTB 532-534.

Chrostowski, W., „Monoteizm. W judaizmie”, NSTB 596-597.

Chrostowski, W., „Nagość”, NSTB, 598-599.

Chrostowski, W., „Nazarejczycy, Nazareńczycy”, NSTB, 616-617.

Chrostowski, W., „Nazireat”, NSTB, 617-618.

Chrostowski, W., „Niewinność”, NSTB, 628-629.

Chrostowski, W., „Noachickie prawa/przykazania”, NSTB, 629-631.

Chrostowski, W., „Obłok”, NSTB, 638-639.

Chrostowski, W., „Ofiara”, NSTB, 646-650.

Chrostowski, W., „Pasterz”, NSTB, 673-675.

Chrostowski, W., „Pielgrzymka”, NSTB, 685-689.

Chrostowski, W., „Poganochrześcijanie”, NSTB, 702-704.

Chrostowski, W., „Pojednanie”, NSTB, 704-706.

Chrostowski, W., „Prozelici”, NSTB, 744-746.

Chrostowski, W., „Reszta Izraela”, NSTB, 773-775.

Chrostowski, W., „Samaria”, NSTB, 793-797.

Chrostowski, W., „Samarytanie”, NSTB, 797-800.

Chrostowski, W., „Samarytanka”, NSTB, 800-801.

Chrostowski, W., „Synagoga”, NSTB, 847-850.

Chrostowski, W., „Synagogalna liturgia”, NSTB, 850-851.

Chrostowski, W., „Szymonianie”, NSTB, 859.

Chrostowski, W., „Świadkowie Jezusa”, NSTB, 865-866.

Chrostowski, W., „Trójca Święta”, NSTB, 901-903.

Chrostowski, W., „Winny krzew”, NSTB, 944-946.

Chrostowski, W., „Zło”, NSTB, 997-999.

Chrostowski, W., „Zmartwychwstanie, zmartwychwstanie ciał”, NSTB, 1002-1004.

Chrostowski, W. „Żydzi”, NSTB, 1013-1020.

Piwowar, A., „Miłosierdzie Boże, II. W Nowym Testamencie”, NSTB, 570-573.

Piwowar, A., „Nahuma Księga”, NSTB, 599-600.

Piwowar, A., „Wiara w Biblii”, NSTB, 929-938.

Piwowar, A., „Władza”, NSTB, 947-950.

Piwowar, A., „Zapłata”, NSTB, 985-989.

Poniży, B., „Mądrość”, NSTB, 539-544.

Poniży, B., „Księga Mądrości”, NSTB, 534-539. 


\section{Część siódma: sprawozdania}

Bijata, K., „Sprawozdanie z konferencji naukowej pt.: «Księga Ozeasza - orędzie, interpretacja i recepcja»", Veritati et Caritati 6 (2016) 499-500.

Chrostowski, W., „«Księga Ozeasza - orędzie, interpretacja, recepcja». X Konferencja naukowa «Interpretacja Pisma Świętego», UKSW Warszawa, 17 V 2016”, CT 86/4 (2016) 5-6.

Rambert-Kwaśniewska, A., „III Międzynarodowa Konferencja Biblijna «Interpretacja i translatoryka biblijna», 7-8 czerwca 2016 r. Ostrów Wielkopolski”, WPT 24/1 (2016) 171-173.

Strzałkowska, B., „Sprawozdanie Seminario di aggiornamento per docenti e studiosi di Sacra Scrittura: «La letteratura sapienziale», Papieski Instytut Biblijny, Rzym, 25-29 stycznia 2016”, CT 86/1 (2016) 217-220.

Stypułkowska, B., „Sprawozdanie z 54. Sympozjum Biblistów Polskich Rzeszów, 19-21 września 2016 r", Veritati et Caritati 7 (2016) 765-766.

Wajda, A.M., „XII Walne Zebranie Stowarzyszenia Biblistów Polskich oraz 53. Sympozjum Biblistów Polskich (Toruń, 22-24 września 2015)”, RBL 69/3 (2016) 379-384.

\section{Część ósma: inne}

Chrostowski, W. - Kowalski, M., „Stowarzyszenie Biblistów Polskich - Członkowie zwyczajni. Stan w dniu 1 VIII 2016 r.”, ZNSBP 13 (2016) 31-308.

Janczak, G. - Kowalski, K. - Lakhmitskaya, T. - Targoński, M. - Wielgut, F., „Polska bibliografia biblijna za lata 2014-2015", BibAn 6/2 (2016) 251-279.

Strzałkowska, B., „Polska bibliografia biblijnej teologii Ducha Świętego za lata 1950-2005”, CT 87/1 (2017) 115-172.

Szymik, S., „Wprowadzenie”, Natchnienie Pisma Świętego w świetle świadectwa tekstów o nich samych (red. M. Wróbel - S. Szymik - K. Napora) (ABL 15; Lublin: Wydawnictwo KUL 2017) 5-10.

Wronka, S., „Ksiądz Jerzy Chmiel (1935-2016) - biblista humanista”, VA 88/3 (2016) 31-33. 